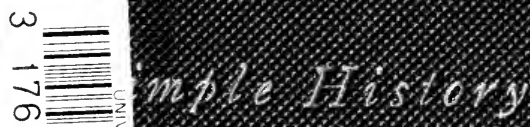

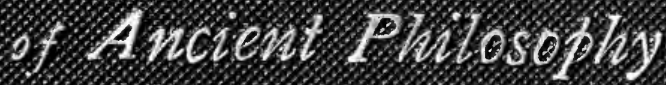

$$
\begin{aligned}
& \infty \\
& \text {. } \\
& \text {. } \\
& \rightarrow= \\
& \omega
\end{aligned}
$$




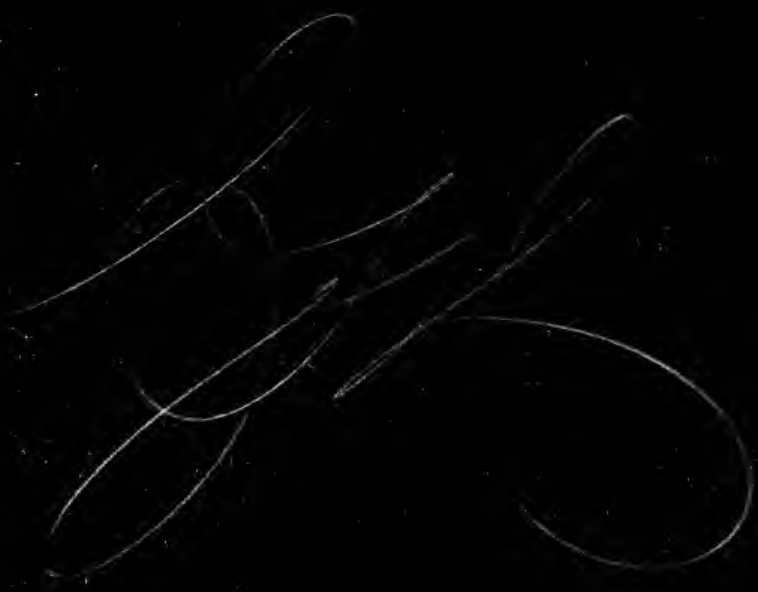


$$
\text { . }
$$ 
A SIMPIE HISTORY OF ANCIENT PHILOSOPHY 


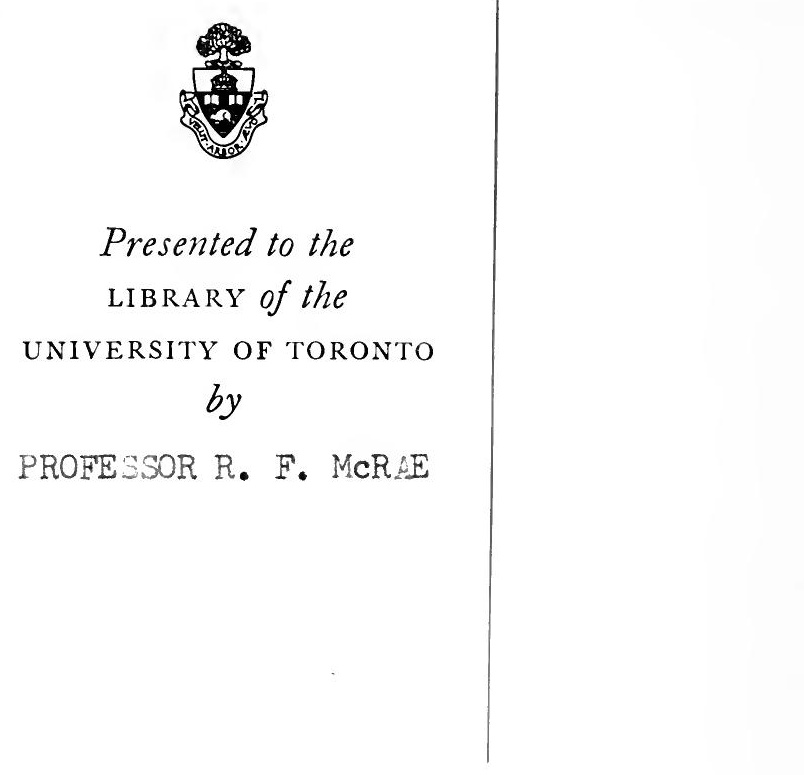




\section{A SIMPLE HISTORY}

$\mathrm{OF}$

\section{ANCIENT PHILOSOPHY.}

BY

W. R. SCOTT, M.A.,

Trinity College, Dublin,

AUTHOR OF

'AN INTRODUCTION TO CUDWORTH'S "TREATISE CONCERNING ETERNAL AND IMMUTABLE MORALITY.",

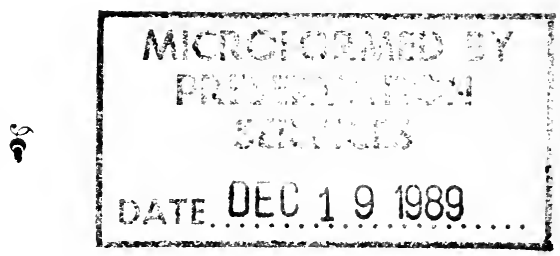

LONDON :

ELLIOT STOCK, 62, PATERNOSTER ROI, E.C. 1894 . 


$$
\begin{aligned}
& B \\
& 1 \% \\
& S 37
\end{aligned}
$$

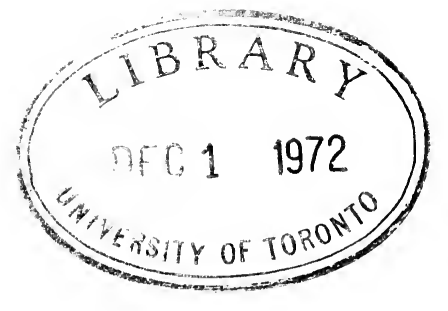




\section{PREFACE}

IT is somewhat anomalous that when the study of Philosophy is generally supposed to begin with its history, there is no book in the latter department that does not demand a previous knowledge of the subject. Hence a person who may desire to possess some acquaintance with the science of mind finds himself, at the outset, gravitating between the horns of an unpleasant dilemma-he can understand little of modern philosophical works without some insight into the previous course of speculation, and the histories from which he should learn it are enveloped in a mist of technical terminology, which presupposes knowledge only to be gained from the treatises of original thinkers-thus, philosophical text-books are unintelligible without a history, and the history is inaccessible without the terminology of the text-books!

The following pages constitute a humble endeavour to aid anyone who finds himself in such an unpleasant position, and in the future $I$ hope to provide a companion volume upon Modern Philosophy; in fact, the portion yet unprinted seems to me to be most needed, and I have already covered some of the ground, but difficulties of treatment have delayed the completion of the work, and in the meantime I venture to publish the present instalment.

As most of the works that deal with this subject have for many years been translations of German text-books, I may be 
pardoned a few words of introduction to one of less importance that has been reared at home. German thought is academic, while ours is more human, and, therefore, I have endeavoured to show Philosophers not as mere thinking machines, but as men struggling with the problems of the world, and as human beings who played their part in some of the stirring scenes of the earlier spiritual movements of civilization.

Secondly, being at liberty to determine my own mode of treatment, I have, in most cases, clearly indicated any word that has acquired a philosophical signification, either by a capital letter, inverted commas, or italics.

With regard to Greek terms I have had some difficulty. Many are of such importance that an explanation secms necessary, but to have done so in every case would have involved an appearance of pedantry extremely disheartening to the general reader. Hence I have availed myself of the original terms only when I felt my own translation may have needed some explanation, but others of importance have been noted in the 'Index of Terms' at the end of the book.

Lastly, I have endeavoured to supply the deficiencies of my exposition by a series of diagrams which group together symbolically many of the abstract principles. This method has been used with advantage in most other sciences dealing with concepts of a like nature, and it has been long established in Logic, but its introduction to Philosophy proper seems to have been hitherto unattempted.

W. R. SCOTT.

I9, Trinity College,

November, 1893. 


\section{CONTENTS}

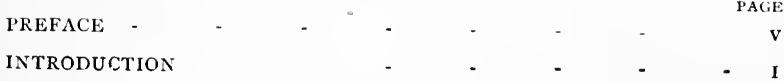

CHAPTER

PERIOD I.

I. THE THREE EARLIEST SCIIOOLS

Sec. 1. The Ionians - - 3

Sec. 1I. - The Pythagoreans - - - 3

Sec. III. - The Eleatics - - - - 5

1I. THE PHILOSOPHy OF CHANGE -

Sec. I. - Heraclitus - $\quad$ - $\quad$ - $\quad$ - $\quad$ - $\quad$ - $\quad$ - II

Sec. II.-Empedocles and the Atomists - - - $\quad$ I3

Sec. III.-Anaxagoras - - - - - - $\quad$ - 16

III. TIIE CLAIMS OF MAN

Sec. 1.-The General Characteristics of the Sophists - $\quad$ - 8

Sec. II.--Individual Sophists and their Method - - 2 I

Sec. III. - The Philosophical Basis of the Proceedings of the

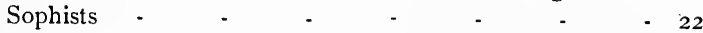

Sec. IV.-Close of the Period - $\quad$ - $\quad$ - $\quad-\quad$ - 23

PERIOD II.

I. SOCRATES - $\quad$ - $\quad$ - $\quad$ - $\quad$ - $\quad$ - $\quad$ - $\quad 25$

Sec. I. - His Relation to the Preceding Philosophy - $\quad-25$

Sec. II. - The Life and Death of Socrates - $\quad-\quad-26$

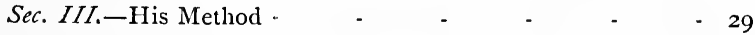

Sec. IV.-His Theory of Virtue - - - - - $\quad 30$

Sec. $V$. - The Lesser Disciples of Socrates - - - $\quad 3$ I 
II. PLATO

Sec.

Sec. II.-His Inner Development - - - - - 35

Sec. III.-The Dialectic or Theory of Ideas - - - - $\quad 37$

Sec. IV. - The Universe and Man - - - $\quad-38$

Sec. $V$.-Ethics and the State - - - - - - $4 \mathrm{I}$

Sec. VI. - Plato's Successors in the Old Academy - $\quad$ - 45

III. ARISTOTLE

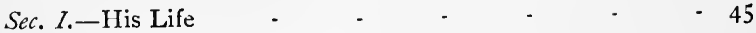

Sec. 11.-His Historical Position - - - $\quad-\quad-47$

Sec. 11I.-Aristotle's Philosophy-(A) Metaphysics - $\quad 49$

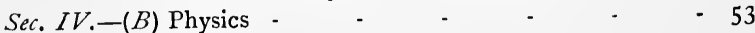

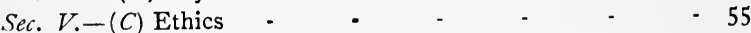

Sec. V1.-The 'Peripatetic School' - - - - $\quad$ - 58

P ER I O I I I.

THE CHARACTERISTICS OF THE LAST PERIOD OF GREEK PHILOSOPHY 60

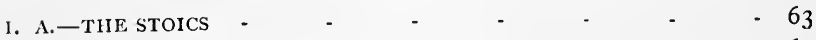

Sec. I. - The Philosophers of the Stoa - _ - - - $\quad 63$

Sec. II. - Logic and Physics - - - - - - - $\quad-64$

Sec. III. - The Theory of Virtue - - - - - $\quad-65$

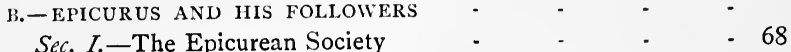

Sec. II.-Logic, or Canonic, and Physics - - - $\quad$ - 69

Sec. III.-Ethics - - - - -

C.-SCEPTICISII IN THE NEIV ACADEMY - $\quad-72$

Sec. I.-Scepticism as a School of Philosophy $\quad$ - 72

Sec. II. - The Scepticism of Arcesilaus and Carneades $\quad 74$

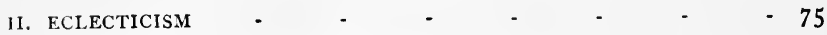

Sec. I.-General Characteristics - - - - - $\quad-75$

Sec. II.-The Fourth and Fifth Academies - - - 76

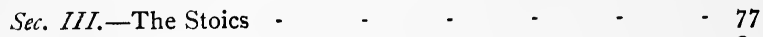

Sec. IV.-The Cynics, Peripatetics, and Epicureans - $\quad 80$

Sec. V.-Later Scepticism - $\quad$ - $\quad$ - $\quad$ - $\quad$ - 80 
CONTENTS ix

CHAPTER PAGE

11. NEO-PLATONISM - $\quad$ - $\quad$ - $\quad$ - $\quad$ - $\quad$ - $\quad 82$

Sec. I. - The Transition from Eclecticism to the Philosophy of

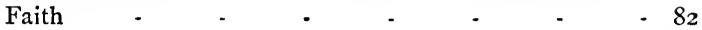

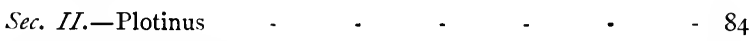

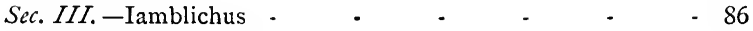

Sec. IV.-The Last School of Neo-Platonism - $\quad \cdot \quad-87$

INDEX OF TERMS AND GLOSSARY $\quad \cdot \quad \cdot \quad \cdot \quad \cdot \quad \cdot \quad-89$

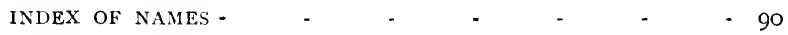

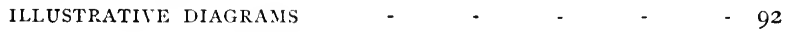





\section{INTRODUCTION}

As Humanity presses rapidly onward, passing stage after stage in quick succession, towards the goal of its development, the marks of distances traversed are forgotten in the haste that urges us forward to gain the purposes ordained to be the reward of our exertions and the stimulus to our hopes. In the history of mankind there came a time when the satisfaction of the gnawing cares of material wants left room for a wider view of things, and gradually the rudimentary forms of the sciences stood forth rough-hewn by man's exertions. As he laboured on, piling knowledge to knowledge, facts began to group themselves in classes, and the toiler who was fortunate enough to mount highest, found other groups around his own, standing like isolated mountain-tops, without connection or unity. The thirst for one path that would lead to heaven was quickened, not appeased, by this discovery, and when men sought a higher unity, Philosophy began. In other words, some method was needed which would complete and, as it were, rule all else that had been acquired by man.

Doubtless such a need arose long before any mariner was found daring enough to launch his bark upon an utterly unknown ocean. To civilized people, like the Chinese and Hindoos, the yearning for one firm chain to bind all knowledge and endeavour must have made itself felt; but it was allayed by the dogmas of their faith. They connected 
together the myriad events and experiences of life, and then believed the chain might be fixed to the religious centre of their other beliefs. But Philosophy must know, while theology believes. Theology begins with heaven and ends with earth; philosophy begins with earth and hopes to reach to heaven.

It was not until the Greeks emerged as a people and a power that knowledge was able to make its last bold stride to realize its own inner meaning. No other people had been so well situated to bring forth and nurture the infant science. Their country stood as a bridge, connecting the sinking civilization of Asia with the sturdy barbarism of Europe. Their schemes for the colonisation of their neighbours led to a healthy friction, which generated new ideas, at the same time removing the glaring excrescences of their religious faith. The agricultural character of their country was also an important element in the maturing of the early Greeks; a soil that readily yielded its gifts but to those who could earn them, taught early lessons of effort, while leaving leisure for mental development and spiritual inquiries. From these two facts it follows that the Greek religion, though apparently mere polytheism, contained the germs of a handmaiden science. It was without either dogmatic system or an organized priesthood, and, therefore, it opposed no obstacle to the free growth of independent inquiry.

The politics of the Greeks, moreover, were even more fruitful in the foundation of Philosophy. With a remarkable genius for the orderly combination of individuals, coupled with a keen perception of their claims, they learned how bodies of men could be best combined in a harmonious whole. To translate the same principle from politics to the grouping of the highest results of all existent knowledge was the beginning of Philosophy. 


\section{PERIOD I.}

\section{CHAPTER I.}

THE THREE EARLIEST SCHOOLS.

Sec. I.-The Ionians.

(a) Thales, one of the seven 'sages of Greece,' is the father of philosophy. $\mathrm{He}$ is said to have been born in Miletus about 640 в. C., and his death is placed between the years 548 and 545 B.C. His contemporaries honoured him for diplomatic tact and practical wisdom, while many records attest his knowledge of mathematics and astronomy. It was but natural that a mind whose horizon was so wide-reaching should divine the necessity of a coping-stone to the sciences. Therefore he sought something into which every portion of nature might be resolved, and from which they all originated. Some beginning of the world was imperative, and a beginning he defined as that 'from which anything originates.' 'This beginning, the primal matter, he declared to be Water, from which all things arise and upon which our earth floats, a supposition not unnatural to a native of Ionia. The reasons justifying this generalization have partly perished; indeed, it is doubtful if Thales committed his thoughts to writing, and the loss is the less in that his importance lies not so much in the discovery of a principle as in the foundation of a new science. 
(b) Anaximander, like Thales, was distinguished by remarkable knowledge, and, as a fellow-citizen and contemporary, he followed the path already marked out. But at first sight his conclusion seems to wander wide of the simple speculations of Thales. Nevertheless, he too started with the same desire to unify the manifold variety of nature. But the 'beginning' is no simple element, but the Unlimited or Boundless. For, he reasoned, such must be the germ of the world, otherwise it would be exhausted in the creation of infinite forms. What exactly the Boundless was, Anaximander seems to have left undetermined; its negative character was its chief attribute, separating it from the bounded and limited existence of matter in its concrete form. Primeval, indestructible, imperishable, without limit or end, the Boundless was at once the parent and the tomb of the diversified life of the world.

The Boundless, moreover, was in movement from eternity. In its motion first the warm was parted from the cold, and from these arose dampness. Dampness gave use to the earth and the air. In its earlier stage the earth was fluid, and as it dried human life began to appear. But the created world is without permanence, it must resolve itself into the primal matter, which will again give birth to successive creations, each again doomed to perish and again be created in ceaseless succession.

(c) Anaximenes lived in the middle of the sixth century before Christ, and like his predecessors was also a Milesian. His philosophy starts from the central thought of Anaximander, that the beginning of all things must be boundless. But he believed that it must be something definite and tangible, a boundless something, not the Boundless as a mere abstraction. He found air to be concrete and also unlimited and in eternal motion. Thus Anaximenes united in his primal matter the concrete characteristics of Thales and the infinite range of the thought of Anaximander.

Air becomes rare or dense; so the primal matter, Air, by 
rarefaction became fire; by condensation first wind, then clouds, water, and, last of all, earth. But the earth, as with Anaximander, resolved itself again back to the primal matter, and so in endless process.

(d) Later Adherents of the Ionic School.-The simpler theories of Thales and Anaximenes found supporters even in the end of the fifth century. Hippo modified the theory that Water was the primal matter by changing it to Moisture. Diogenes of Apollonia and Idæus followed Anaximenes. The former especially supported the older doctrine against later theories and criticism.

\section{Sec. II.-The Pythagoreans.}

(a) The Pythagorean Society.-During the life of Anaximenes there arose a new system of thought. Pythagoras, well known as a scholar, removed from Samos to Crotona in Italy, where he gathered round him a body of followers bound together by a semi-religious tie. The new society was pledged under an oath of secrecy to reform their lives and practise moderation and self-control. The members cultivated all the sciences and arts of the time, devoting themselves chiefly to mathematics.

Proselytism is the usual manifestation of a vigorous spiritual life, and accordingly the early Pythagoreans soon endeavoured to induce others to follow in public the same principles that dominated the secret life of the society. Gradually many of the cities of Magna Græcia adopted the new scheme of life, until a strong political reaction forced Pythagoras himself to fly from Crotona to Metapontum. The flight of the leader was a signal for the burning of the central meeting-place of the order, after which many of his disciples lost their lives. Early in the fourth century Archytas of Tarentum called together, for a time, the scattered members of the community, which rose to great influence as a religious body, while its spiritual tendencies steadily declined. 
(b) The Principles of Pythagorean Philosophy. Thales and his followers sought some beginning for the world by endeavouring to reduce the manifold varieties of matter to one from which they might be supposed to originate. Thus they aimed at the discovery of a beginning.

The general tendency of the Pythagorean society was to seek some characteristic which was common to all things. Perhaps they were animated by an unconscious hope that this characteristic might lead to the discovery of the beginning, the search for which was the animating principle of early philosophic effort.

The one feature in which all things agreed was the fact that they possessed Number. Thus Number is the continuous chain that binds together infinite diversity, and number can be applied to all things.

From this they unhesitatingly concluded that 'All is Number,' thereby leaving the relationship between numbers and things completely undetermined.

Number, moreover, is odd or even, and the even can be equally divided, while the odd cannot. As the even can be divided to an unlimited extent, number contains within it the opposite principles of the Boundless and the Bounded, and since Number is the principle of all things, everything must be either bounded or unbounded.

But Number gives us this harsh antithesis only in analysis; it has also the characteristic of Harmony, which is eminently the reconciliation of opposites. Therefore the diversity of things as originating from Numbers is subjected to an unalterable law of unity, and the world is delicately fitted together in the symmetrical proportioning of its parts, each to aid in the beauty of the whole.

(c) The Application of these Principles.-As there is no special exponent of the Pythagorean teaching, it is natural to expect much diversity in the practical application of their principles. Moreover, when it became necessary to assign 
number to each thing, the result exhibits so many renderings that in most cases none can be specially accepted.

I. In the Pythagorean account of the actual world the creative energy must have been One, and this was Hestia, the central fire, 'the citadel of Zeus.' As One, the central fire belongs to the Bounded, and it gradually attracted towards it the unbounded. Around it move the earth and other heavenly bodies. Of the numbers assigned to individual things, few have any significance beyond the obvious statement that the point is one, the line two, a surface (or superficies) three, and the solid four.*

2. As applied to moral action, the number theory necessarily gives vague results. Probably, because virtue is the unity of aim of life, it was defined as a Harmony. Justice is equality multiplied by equality, because it returns equal for equal. The remaining ethical maxims of the Pythagoreans refer to the inner life of their society, and have no reference to their philosophical system.

(d) Influence of the Pythagoreans. - The consolidated influence of opinions, perpetuated by the numbers and lasting life of a society, extended farther than the previous discoveries of isolated individuals. Thus, thinkers who had kept apart from the charmed circle of the mystic dogma of the Pythagoreans often exhibited traces of their doctrines. Hicetas of Syracuse adopted the principle of the revolution of the earth, but he made it revolve upon its own axis instead of round the central fire. The comic poet Epicharmus also seems to have * I. is the point ; II. the line ; III. the superficies; IV. the solid.
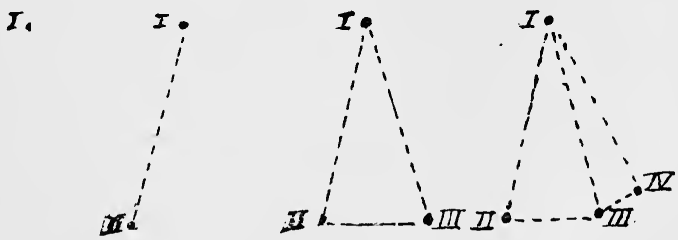
been influenced by Pythagorean teaching; and in many philosophers, such as Hippasus of Metapontum and Ecphantus, it has been combined with other theories.

\section{Sec. III.-The Eleatics.}

The number-theory of the Pythagoreans contained the opposed principles of one and more than one, or the One and the Many, which were united by the further principle of Harmony. The next important step was made by a body of philosophers, called Eleatics from their place of residence. To mount higher towards the explanation of the world, it was necessary to resolve the antithesis between what was one and more than one. This was accomplished by placing truth in the former and denying it in the latter. Philosophy seeks unity, and unity can be found, they argued, only by denying the truth, and consequently the existence of that which seems not to be one. Therefore, the whole universe is one grand unity, and what appears to be plurality is but the semblance unity adopts to the dim eyes of humanity.

The completion of a doctrine, so far in advance of their predecessors, was the work of three generations. Xenophanes denied the plurality of Gods, fixing the chief characteristic of divinity in its essential unity. Parmenides directly extended the same doctrine to the whole field of inquiry, and Zeno approached the same result negatively by proving that everything that was plural was but a standing contradiction, and, therefore (by implication), what was One is alone self-consistent and true.

(a) Xenophanes.-The anger of Xenophanes was roused by the popular representation of the Gods. Surely it was a mockery of Divinity to deify the frailties of humanity. Nay, more, to say there are Gods is a weakness of undeveloped intellect, for God must be the highest of all, and, therefore, One, eternal and unalterable. 
When he looked at the boundless changeless dome of the heavens, he felt that he saw the One that drew the yearnings of humanity towards itself. The world was One and God-the great unity that contains within it all things.

(b) Parmenides saw that the divinity of the God of Xenocrates was but the divinity of truth. Because the One, or the world, or God was unity, it was consistent and true. Therefore, the One was the only true existence. What was false or many by its plurality forfeited all claim to true being. True 'Being,' on the contrary, is one, indivisible, self-complete, self-contained, equally distributed, changeless and imperishable. Separated from the divisions of time and space, and shut out from the many and contradictory reports of the senses, reason faced the one immutable existence alone in the void of thought!

But if 'Being' be one, and one only, how is it that men seem to see plurality in all things? This Parmenides believed to be a semblance of the one true existence travestied by the cunning comedians our senses. Still, how can plurality, what in strictness is not Being, even seem to be? The explanation forms the second part of the epic of the philosophy of Parmenides. Being is Fire, the active vivifying principle opposed to dull night and the gloom of nothingness. From the combination of these arose the earth and men. In our minds is found the same antithesis, and each elemental part recognises that which is like it, and thus we lose true Being, the true, and the One in the semblance of plurality.

(c) Melissus and Zeno of Elea.-Melissus hoped to fuse the principle of Parmenides with portions of other philosophies. In many points, however, he remained true to his predecessor, especially in his steady advocacy of the unity and indivisibleness of true Being. He added to the doctrine by denying the plurality involved in the division of space and time.

If Melissus partially endeavoured to be the bearer of a flag of truce to other doctrines, Zeno of Elea was the uncom- 
promising herald of war. In his life and philosophy he was alike at odds with the world. At Athens he was met by the facile sneers of those who had adopted the easy doctrine of the Ionics, and he turned against them the formal weapon of insidious attack. He did not directly maintain the truth of his own theory; but the issue lay between his and another, and that other, he maintained, was self-contradictory. There is little mention in Zeno's work of the One, but he proved it to be the sole existence by disproving the existence of the Many. This method was known as dialectic.

Parmenides proved that only the One $I s$. Zeno began with the last word of Parmenides, and maintained that what is not one cannot be really said to be ; and, therefore, by implication 'Being' is One.

Plurality is the illusion of our weakness, and mocks us when really investigated. If we trust for knowledge to what is Many, we build our faith upon a fallacy, and our reason is the sport of hidden contradictions. For space and time are the special demesne of the Many, and they are jointless spectres ever one in appearance, never one in reality. The numbers of things in space, and of occurrences in time, each of them partake of this elusive character. What seems to be one in space is but bound together by a carefully-balanced contradiction, for it is beyond protest both immensely great and miserably little. Analyze it, and it must be composed of parts, and these parts of lesser parts till they can no longer be divided. But to be no longer capable of division, the last parts must be without magnitude, and therefore their total is infinite littleness. On the other hand, take another point of view, and the parts composing the body must be separated from their neighbouring parts, and these from those adjoining them, and so on until the mind is fain to admit that that which seemed one whole, and was proved infinite in smallness, has now become infinitely great.

The same illusion mocks us in the occurrences of time. It seems that Achilles, fleetest of mortals, will overtake the sluggard 
tortoise. But spectre Time is the judge, and, let the tortoise gain the slightest start, notwithstanding the hero's speed, he can never regain the ground he has lost. For when Achilles has gained the stage that marks the start of the tortoise, it must be still ahead; while he reaches that point the tortoise still plods on, and so the race can never be ended, and those we seem to see are but the illusion of the traitor multitude self-betrayed by incongruity and internal dissension.

\section{CHAPTER II.}

\section{THE PHILOSOPHY OF CHANGE.}

\section{Sec. I.-Heraclitus,}

(a) His Position.-In the hands of the Eleatics Philosophy had become bankrupt by their hasty desire to reach the goal before it had been legitimately won. Reason impetuously sought its destiny in the Unity of 'Being,' and found but a void where it sank nerveless and exhausted. To this procedure a counter-tendency was opposed by Heraclitus, who, fleeing the void that first allured and then engulfed the reason of the Eleatics, found truth only in changes of the world as they appeared to sense. The last words of the Eleatics were 'Being' alone is One; the first maxim of Heraclitus was all things change; Being and non-Being are alike one, for both are but fleeting manifestations of the ceaseless law of alteration. Thus change was banished by the Eleatics only to be recalled by Heraclitus and enthroned as the final and universal law.

(b) His LifE. - With Diogenes of Sinope, Heraclitus divides the title of the 'Misanthrope of Ancient Philosophy.' Living between the years 535 B.c. and 475 B.c., his birth touches the closing years of the last generation of the Ionics, coinciding with the migration of Pythagoras to Italy, and his maturity 
runs parallel with that of Parmenides. Of a haughty temperament and strong aristocratic opinions, he associated but little with his contemporaries, and he sought truth by his own method. Therefore, he cared little for making disciples, and the disjointed sentences in which his utterances are clothed seem rather to mystify than enlighten the reader. Hence, by the time of Aristotle he was named the 'Dark' or 'Obscure.'

(c) The Principles of his Philosophy.-The thought of Heraclitus might be said to begin where the poem of Parmenides ends. When the one sole existence 'Being' had been defined, it was necessary to explain the manifold semblance of the world, that which in its real nature is not 'Being' but illusion. Such a distinction, according to Heraclitus, was unreal ; 'Being' and 'non-Being' cannot be severed, for all things change from one to the other. 'All things change, and naught abides.'

To distinguish, moreover, 'Being' as one is equally false; for everything under a mask of unity conceals infinite diversity, and whether things appear one or many is philosophically unimportant. As before, the magician Change is at work, dividing one in many, and binding the fragments into one.

The law of Change was too abstract to remain the expression of the continual alteration of the world. Sometimes Heraclitus reached the idea, and again the influence of the Ionics draws him back to something concrete, at once the cause and the expressinn of the change. Thus, in demi-symbolism, flame or vapour is the cause of ceaseless alteration. In endless process under its guidance everything passes from one state to its opposite, and all existence is an oscillation between contradictions. We can see nothing but contrariety, and so strife might be named 'the parent and king of all.' But, as with the Pythagoreans, the range of opposition is fixed, and thus even in it there is harmony.

(d) The Theory of THE World.-The fire that symbolizes Change passes into water, and water into earth. But 
there is no stability in any of these; when the series is completed earth changes to water, and water to vapour, flame, or fire. As the world is the theatre of all such changes, it manifests them all, varying between nebulous vapour and the apparently stationary existences opposed to it.

The life of man, like all else, is a portion of the great world vapour, and subject to the same perpetual change. Fleeting impressions form its spiritual nutriment, and hence it might be anticipated that Heraclitus would place truth in them. But unconsciously he was influenced by the Eleatic contempt for the fleeting shadows that fell upon our minds whence we know not. Though Change rules all with iron tyranny, man has a meagre state where reason gives the law. Reason must be the judge of truth, and the 'senses are but bad witnesses.' In our conduct we should submit ourselves to the unalterable law of 'Change' with contentment, recognising this law itself is changeless, and therefore of the same order as what man calls Divine.

\section{Sec. 11.-Empedocles and the Atomists.}

(a) The Tendency of Both.-Heraclitus headed a new generation of thinkers by his enunciation of Change as explanation of the world. Inside Change there was much to be learned, and a careful analysis of it was the work of his successors. If Change be not a delusion, as Zeno of Elea maintained, there must be some reason for its existence. From another point of view it may be said that the Eleatics bequeathed Being, the One and unchangeable as truth and the world we see as a falsehood; with Heraclitus, on the contrary, the world because it is plural, in its complete subjection to Change, is the sole truth. Empedocles and the Atomists had to face this alternative, and they endeavoured to solve the riddle by manacling the Proteus that had mocked the Eleatics and bewitched Heraclitus. Both asked, "Why should all things be subject to Change?' and the answers are closely related, 
though based upon different principles. Empedocles had a dawning presentiment of the universal diffusion of force, and his answer howers between a scientific and a merely poetic use of the idea. The Atomists saw Change exhibiting the continual characteristic of change of place, and their answer was a microscopic analysis of matter, which gave parts so minute that their ceaseless combinations seemed to explain the problem of all alteration. Thus it may roughly be said that Empedocles endeavoured to explain Change dynamically, the Atomists mechanically.

(b) Empedocles. - Like many of the earlier Greek philosophers, Empedocles was an ardent politician, and like Pythagoras he gained the character of a prophet, and even a worker of miracles. It is probably to this side of his life, rather than his philosophy, that we should attribute many of the ethical doctrines commonly connected with his name.

Empedocles differed from Heraclitus in attributing less finality to Change, while he was more profoundly impressed by the need of some permanent reality that would remain unaltered, however disguised. Thus where he began to recede from the position of Heraclitus he approached the pure Being of the Eleatics. But in touching their main principle he again diverged in a line peculiar to himself. The permanent Being that changes is not one, but divided into four fundamental forms, incapable of further analysis. These he named 'roots of all.' They were the four elements-fire, air, water, earth - which cannot be altered save in their mutual composition.

To compound the elements to form the objects met with in the world a force was needed. Affinity and Repulsion (or, as Empedocles named them, Love and Hate) bring together and separate the elements in endless mutation.

At first the four elements were held together by Love in the primal world until Repulsion separated them. But before the extreme of disunion was reached, the action of Affinity created 
a whirling motion of the divided substances. From this arose the universe, self-centred in endless rapidity of revolution.

On the earth lower forms of life were the first to appear. Gradually as Affinity mastered Repulsion, living organisms perfected themselves until mankind was reached. As we are composed of the elements, so each element recognises that which is akin to it, and we desire what attracts our whole nature, and avoid what repels it.

(c) The Aтомists. - The completion of the Atomistic theory was the work of Leucippus and Democritus. The principles of the theory are due to the former, and their application to the younger and better-known philosopher. Like Empedocles, they took up the problem bequeathed by Heraclitus, and the relation of the two solutions may be illustrated by the connection between the Ionians and Pythagoreans. The qualities of matter intrude themselves upon our senses, while its quantity has been a matter of subsequent discovery. Thus, the first school of philosophy found the former, the second inferred the latter, to be the chief characteristic. Similarly, Empedocles based the permanent element in Change upon a qualitative distinction, the Atomists upon quantity.

Being was everywhere the same in kind, but it was divided into an infinity of indivisible parts, which were called Atoms. The Atoms differed only in shape and size.

As Being they fill space, and they are separated by the Void, hence the chasm between Eleatic Being and non-Being is bridged by the permanent existence of a plurality of Atoms, which demand emptiness to maintain their self-completeness in isolation.

From eternity the Atoms streamed through space, the larger, and therefore heavier, falling more rapidly than the smaller and lighter. Impelled by this law, the larger Atoms travel more rapidly, and bound against the lighter. In this ceaseless bound and rebound the whole infinity begins to whirl in a complex mass. As they crash together, Atoms of different 
shapes glide away, while those of similar form remain together in a close or loose embrace, according to the pressure to which they are subjected.

In the universal Atom-stream, our world is but one of many where the Atoms have been compressed into varied combinations. The grouping of like-shaped Atoms gives the purer substances, and those more compound are composed by a temporary union of the varied forms. The globular Atomforms are the highest, and these form the most ethereal of things, vapour or fire. Of the globular Atoms the smoothest make the human soul, the highest element in man. The intangible irradiations of Atoms from those already compressed into bodies stamp themselves upon our souls through the eye. and thus we learn the existence of the world around us, perceiving each group of Atoms by the counterparts in ourselves.

Man, though high in the Atom-world, is not its highest product. Greater and still more complex than he are beings who haunt the upper air, and the Atoms flowing from these to us in our dreams give us the idea of Gods.

Thus the change of the world is no longer unexplained. Fate is an unappeasable taskmaster to the Atoms; there is no rest, and they fulfil their destiny in ceaseless movement. Growth, decay, beginning and ending, are but the grouping and ungrouping of myriads of indivisible unities, which thus fulfil their destiny. The world shares the instability of individual things, and

\footnotetext{
'The flaring atom-streams, Ruining along the illimitable inane, Fly on to clash together again, and make Another and another frame of things For ever.'
}

Sec. III.-Anaxagoras.

(a) His Connection with his Predecessors.-As the birth of Anaxagoras is not far distant from those of Empedocles and Leucippus, so his philosophy is likewise an attempt to meet 
the same problems. $\mathrm{He}$, too, found a permanent basis for change, uniting the leading characteristics of the two preceding systems. With the Atomists he held an infinity of minute particles, but differing from Atoms in being divisible and each of a specific quality, therein agreeing with Empedocles, from whom, again, he differed in that the qualities of the 'germs of things' was complex, not elements. Thus he diverged from both in making the quantity and quality of the primitive constituents of things divisible and analyzable. Therefore, of the three attempts to find a basis of Being as the subject of Change, the first is mainly founded upon quality, the second upon quantity, and the third is a union of the two cancelling inconsistent attributes. For the 'germs' of things, while infinite in number and indestructible, are miniatures of existing things; bones contain myriad parts of bone-stuff from which the whole is composed, and so with all other things.

As with the Atomists, the ' $g$ erms' are subject to a whirling motion, but-and this is the importance of Anaxagoraswhence comes the impetus? To assign it to Fate was building the universe upon an empty name, and Chance was but a cloak to hide the want of knowledge of the true cause. Moreover, the original state of the germs of the world was a chaos of baffling confusion, and how could it become the well-ordered world we see around us, unless the cause be able to arrange it? Therefore, the mover of the germs or beginnings of things must be Mind.

(b) The Application of his Principles. - There are thus two opposed principles for the formation of the world. On the one side, the germs of things ( $\left.\sigma \pi \epsilon^{\prime} \rho \mu \alpha \tau \alpha\right)$, or, as they were after-

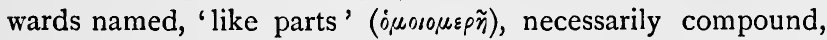
containing all the parts of the world mingled together in an abyss of chaos. On the other is Mind, simple in its nature, ruled by itself alone and pre-eminently gifted by its purity. As Intelligence, its function is that of ordering and arrangement-the transformation of Chaos to Kosmos. It does this 
by a whirling movement of the formless mass. Gradually by their rotation germs are grouped according to their most universal points of agreement ; and first, the damp and heavy, uniting, sink towards the centre, while round them revolve the light warm germs. As the movement continues, things as we know them begin to emerge, yet never with finality, for similar parts are never wholly grouped together to the exclusion of those that differ from them ; and so the movement ceaselessly continues, ever producing change and novel combinations.

By this mind-theory of Anaxagoras, Philosophy began to awake dimly to a consciousness of its own power and the higher elements in man. To realize the thought was the work of others, for the supreme intelligence of Anaxagoras is only a matter-mover; and thus his name fitly closes the earlier speculations concerning nature, while at the same time mistily indicating a new and hitherto untrodden road. As closing the earlier sequence, he seems to bind together the salient characteristics of preceding philosophers. The chaos of the germs of things reminds us of the Unbounded of Anaximander, while opposed to it is the Unity of Mind, thus carrying out the Pythagorean division of the numerical character of things. The pure Being of the Eleatics is centred in Intelligence, whose formative power in its existence is the dynamical principle of Empedocles, and by its application it produces the process and change of Heraclitus. Finally, the germs obviously resemble the Atoms.

\section{CHAPTER III.}

THE CLAIMS OF MAN.

Sec. I.-The General Characteristics of the Sophists.

WITH the investigation of the problem of Change the direct philosophy of the first period ends. At first flying high above the earth, or buried in its inmost recesses, philosophical investi- 
gation was ignored by all but the curious. The time had now come when the search for truth must collide with the beliefs of practical life. From each side tendencies of different natures had been gradually coming together.

In Greece of the fifth century culture and new ideas had undermined the whole edifice of religious worship, and with its fall the morality of the State had suffered. For the poetic attributes of the popular religion had been banished by the infant prattle of early science, and the skeleton that remained grinned horribly at men's blind efforts after right. Public life had likewise changed. A slow revolution had silently been at work, and little was needed save utterance to show that the old political maxim had been changed from the unselfishness of 'One for all' to the utter egoism of 'All for one.' Under the mask of a united democracy each individual sought his own will under cover of that of the sovereign people. Thus, instead of the old political unity, there arose a continual divergence of interests, and consequently a wide-reaching scepticism in the basis of law and the State.

To those who watched the tide of events the same tendency appeared in the early growth of philosophy. They saw the search for a beginning merged in the rock of Being, which was swept away by the ceaseless waves of Change. The times did not give practical men the strength of mind or will to wrest a new solution from the difficulties before them. Doubt was in the air, and those who aspired to lead saw it the more, and it only remained to enunciate the universal scepticism.

This was unhesitatingly pronounced by the Sophists, or 'wise men,' who endeavoured to control the seething elements of the rising intellectualism of their day. 'They saw tradition stripped of its sanctity; and philosophy, too, must forego its claim to the leadership of the sciences. As the will of the individual had emancipated itself from the tutelage of the state, so his opinion must decide what is true, and philosophy was but an 
intellectual tyranny to be replaced by the milder rule of 'the Wise,' or who persuaded when others convinced.

Persuasion was all that the individual in his new power would take from the wreckage of the preceding system of religious, philosophical, political and social life ; and the mission of the Wise was to cultivate the art for themselves and teach it to others. Philosophy they touched but to shatter, as prescribing a law to the sovereign individual. Permissible as an educational discipline for the refutation of the views or wishes of others, it was childish in middle life and a crime in the old.

But the state is composed of many individualities, and he who rules must be able to control them. He must be able to make 'the worse appear the better reason' at will, and thus some of the later Sophists were prepared at a moment's notice to maintain either side of any question. In the new state of things the same wish dominated the conduct of all who were ambitious, and thus the Sophists were attended by numerous followers who endeavoured to cultivate the same arts. By a strange transition, philosophy was supplanted by Rhetoric, and as speakers the Sophists wielded great influence. Travelling from city to city, they neglected no art to proclaim their own sufficiency. Everywhere they dazzled the young, and received large sums of money for their teaching. Popularity was their main object, and it was readily gained, for the substitution of expression for thought is always popular and eagerly welcomed. Eminently men of the world, they represent in the history of civilization the first attempt of the quickwitted and clever to appropriate the labours of the scholar while scouting his toil; in the history of philosophy, without being themselves philosophers, they are the brilliant champions of individual thought and the claims of the mind to primary and paramount consideration. 


\section{Sec. II.-Individual Sophists and their Method.}

Protagoras of Abdera was the first to lay claim to the lofty title of a wise man. His birth is assigned to about 480 B.C., and he is said to have studied philosophy in early life. As a 'wise' man he gave out that his mission was to heal the souls of men by curing them of the vain desire to catch a phantom truth, and teaching them instead to nourish such thoughts as were profitable. In return he received large sums of money as he wandered from city to city in Greece, until the Athenians burned his book and expelled him from the city. The charge of Atheism was founded upon the opening sentence of his treatise upon the Gods. 'As for the Gods,' he said, 'I have no means of knowing whether they exist or not, for there are many hindrances besides the obscurity of the subject and the shortness of the life of man.'

Gorgias, a contemporary of Protagoras and a man of overbearing ostentation of manner, was a native of Sicily. He was selected to represent his townsmen of Leontium in a negotiation at Athens, where he remained for some time as a Sophist, teaching rhetoric and practising politics. After leading the usual wandering life of the Sophist, he settled at Larissa, in Thessaly, where he died at over a hundred years of age.

The wisdom of Prodicus gave rise to the proverb, 'Wiser than Prodicus.' He was famed for his grammatical discoveries and moral precepts, and Socrates is said to have attended his lectures.

When the profession of the Sophists had become famous, their ranks were largely augmented by men who exaggerated their faults and went to still greater lengths to secure popularity. Amongst these may be mentioned Hippias of Elis, who boasted of great knowledge in Mathematics, Astronomy, History, and Physical Science. Thrasymachus was a rhetorician. Euthydemus and Dionysodorus, the central characters of one of Plato's dialogues, gave instruction in military tactics. Minor Sophists, 
while professing all sciences and arts, gave special attention to one study to dazzle the more effectually those whose gifts they wished to attract. As a body they were the intriguers, public speakers, popular teachers, critics and leaders of the cultured scepticism that called their arts into being, while growing under their brilliant personalities and striking powers of expression.

\section{Sec. III.-The Philosophical Basis of the Proceedings of the} Sophists.

To make 'the worse appear the better reason' was the aim of the Sophists. Underlying their practical procedure there was the theoretical principle of disbelief in any fixity of knowledge. As Heraclitus taught, all things were carried along the great river of change, and man himself with the rest; hence we must affirm that each thing is as it appears at the moment. But the appearance can only be observed by man, and therefore, though himself but a drift upon the stream of change, he is, in virtue of his faculty of feeling, a register of change. 'Thus man is the measure of all things.'

Man, as the standard to measure all that is, must again be dissolved into his elements. He can but measure through his senses, and these give a chaos of individual impressions all different, many of them contradictory. Moreover, the impressions of no two men agree, and thus the same sensation may be real to one, unreal to another. Hence nothing can be affirmed to be true, nothing false. Contradictory assertions are each of them but blank documents, to either of which we may affix our signature, as led by caprice or the fickle feeling of the moment.

If there be no universal truth there is no universal law. As sense is the blind recipient of the little light we can gain, so in action we must follow the same guide, and our sole concern is its gratification.

Hitherto man had been restrained from using his power of ' measuring' his surroundings and adapting his action to the 
results. In morals he was restrained by a myth of the power of the Gods, invented by politicians to save themselves and cramp his freedom. In the State he had been taught that law was founded upon an unalterable basis fixed by nature. But is not man, the measure of the universe, his own lawgiver, and can he be denied the right of holding for law what satisfies himself and can be won as the reward of his adroitness or energy?

These conclusions were not drawn by some of the earlier Sophists; on the other hand, they represent a moderation ridiculed by their successors. Gorgias, for instance, though a contemporary of Protagoras, advanced beyond him in his sarcastic refutation of the current beliefs. He used the trenchant dialectic of Zeno to demolish the whole frame of the world, which he named the 'Non-existent.' He shaped his argument with forensic acuteness to prove Nothing could exist, and even if it could exist it could not be known, and if known it could not be communicated.

\section{Sec. IV.-Close of the Period.}

The first period in the history of philosophy has been named its youth or the time of struggle. With boyish confidence, the earliest philosophers demanded a beginning for the infinite diversity of the world around them. The general solution of the Ionics was to dignify one of the forms of concrete existence by naming it the primal matter. The Pythagoreans abstracted all material characteristics, and founded their system upon the form alone, which they found to be number. Mounting still higher, the Eleatics stripped number of its plurality, and gave philosophy the firm foothold of pure Being in its unity.

Change, however, flitted on through the number theory and carried away ideal Being. With chastened ardour the next group endeavoured to explain the problem with unabated hope. Side by side with the mechanical theories, Anaxagoras found the primal motive force for the germs of the world in Intelli- 
gence, leaving the discovery he scarce understood to be completed by a new generation.

To carry on the growth of discovery, the ground must be prepared, the stubble of the earlier theories cut away, and the seed preserved for those who followed and who could understand. This was the work of the Sophists. They represent the youth of philosophy vanquished in its first confident struggle with the problems of existence. Returning from dearly-won victories, the spoils are found to be but barren trophies when compared with the field of real life. In truth, the comparison was the sole victory. The meeting of philosophy and life, of thought and the world, was especially momentous, A light seemed to break forth over the shattered remnants of both, at first leading to doubt, and by doubt to the necessary condition for new discovery. Thus the Sophists prepared the ground for their successors.

After them there was no exemption from the search-warrant held by the mind. All that was, all that was thought or done, was open to doubt, and therefore to inquiry. The mind was awakened to claim precedence instead of dreamily waiting for the impressions thrust upon it from without. None but the ignorant or indolent could rest in what was taken for granted as exciting the imagination or pleasing the ear. The coming philosophy must part with assertion and journey forward with proof. When all that men hold dear was subject to reproach, the time had come for a commanding genius to recall the banished ideals and reinstate the fallen dignity of truth and manhood. 


\section{PERIOD II.}

\section{H A P T E R I.}

SOCRATES.

Sec. I.-His Relation to the Preceding Philosophy.

THE man who fully appreciated the tendencies of time, raised himself above them, and pointed a new way to philosophy, was Socrates. Looking back, we see his remarkable personality as the result and directing power of the labours and speculations of those who had gone before him, while he seems in many respects opposed to them all. His mission was to reconcile the contradictions opposed by time in the presuppositions of previous theories. The simple generalizations of the earlier philosophers had been sneered away by the Sophists, as the vassalage of the mind had been remitted to give place to the democratic tyranny of individual opinion, and Socrates was to decide the new position of self-consciousness as it slowly emerged as a power in philosophy.

To make the mind a dumb handmaiden of physical investigation, he held, was to wander in a wrong direction at the very outset. Summoned by the progress of knowledge, the express command of the oracle he most revered, 'Know thyself,' was continually ringing in his ears, and its reverberation in his soul directed his thoughts and method. Self-knowledge filled his mind as a region unexplored, and fraught with boundless possibilities of discovery. 
On the other hand, while indirectly influenced by the Sophists, he was the unflinching foe of the intellectual petulance that denied truth, because the search was long, and the sanction of law, because it galled them. Human egotism was flattered by being elevated 'to measure' the universe, but the countless and diverse feelings of men have no stability, and 'the measure of all things' is as fleeting as the evanescent shapes that bear him away. Instead of the motley and uncertain 'man' of Protagoras, Socrates was to find what in humanity could be the canon of all he might believe and all he ought to do. Now that scepticism had done its work, Socrates must seek a new method to lay again the foundations for a fresh search after truth.

To accomplish this he gave the world a life instead of a theory-a life opposed to the Sophists at every point. They were rich; Socrates was poor. The Sophists taught for money; Socrates in his poverty asked not even thanks. They called themselves wise, and professed to teach; he professed ignorance, and entreated to be taught. They were ostentatious, and he was humble. They were men of the world, living at courts and flattering the rich; he sought the poor, and spoke his mind before a reckless mob, or even to his friends. Such a life was his sole legacy to posterity, and it was an incontrovertible example of the existence of a nobility of soul that had been apparently banished by the specious arguments of the Sophists.

\section{Sec. II.-The Life and Death of Socrates.}

Socrates was born in 470 B.c., or early in the next year, thus following closely upon the earlier Sophists, Gorgias and Protagoras. His father was a sculptor, and his mother a midwife. The art of the former he is reported to have practised early in life, and he often uses his mother's calling as symbolic of the help he endeavoured to give those whom he found labouring with ideas they were unable to bring forth. Of his youth 
there are few accounts. His marriage with Xantippe has linked his name with that of a shrew, and the virtue of more than ordinary conjugal patience. As a citizen he took part in the government and wars of Athens. During the campaigns he was distinguished by his bonhomie and endurance. None bore better the scarcity of provisions and hardships of a winter bivouac; when others remained in their tents or crept out shivering in furs, Socrates wandered over the ice barefooted, with only his ordinary clothes, shaming the effeminacy of his companions. In the heat of battle he saved the life and arms of his friend, Alcibiades. In the rout at Delium he retreated calmly, with a majesty of mien that warned his pursuers to respect the greatness of a soul that knew no defeat. In public life he braved both the tyranny of the 'Thirty' and the rage of the Democracy. When ordered by the former to execute an unjust sentence, he added to the nobility of his conduct by the simplicity with which he tells it: 'The other four went to Salamis and fetched Leon, but I went quietly home; for which I might have lost my life, had not the power of the "Thirty" shortly afterwards come to an end.* Later, when in the peculiar administration of justice at Athens, Socrates was presiding, the mob became furious at the denial of the unconstitutional sentence they demanded. They clamoured for an impeachment of those who withstood their pleasure, and all but Socrates yielded. He alone stood firm without flinching, and though one against the people, his uncompromising attitude secured an adjournment for the day of his office.

In social life Socrates was a strange figure; barefooted, shabby, with snub, upturned nose, protruding eyes, and unwieldy frame, he sauntered from place to place like Silenus in the flesh. When he spoke, the listener was sometimes charmed in spite of himself, sometimes goaded by a succession of urbane and trivial questions to anger which, strange to say, left him the

* 'The Dialogues of Plato,' translated by B. Jowett, M.A., vol. i., p. 365 . 
germ of an idea. To teach people in spite of themselves by the commonplace dialogue of everyday life was the aim of Socrates. He was everywhere ready to combat the growing egoism of the people. Who could refuse to enlighten the humble, ugly old man? No one could deny an answer to his polite questions. Gradually, with exquisite tact and skill, he placed before the astonished teacher the whole disordered bundle of thoughts that had before seemed so consistent and valuable. Those who were pretentious deemed such teaching unwarranted impertinence, but young men of open minds gathered round the great-souled critic of the life and manners of the nation. They admired his keen wit and wondrous subtlety, while the unostentatious simplicity and remarkable magnetism of his character irresistibly recalled them from luxurious indolence to the noble ideal of a life permeated with unselfish thought. It was thus that Socrates endeavoured to regenerate Athens by educating her sons.

The complete self-renunciation of such an aim awakened no response in the cultured selfishness of the time. When Socrates had become old in work, he was accused of perverting the youth, of slighting the Gods of the people, of introducing new Deities. He was summoned before the tribunal of justice, and answered his accusers with the dignity of the innocent and the playfulness of a large mind pleading before the exponents of errors he had judged and forgiven. Without any plea for sympathy or excuse, he told the simple tale of a life of poverty and teaching-how he had everywhere found ignorance in those who boasted knowledge, how he alone of all the Athenians knew that he knew nothing, how simply he had sought to lighten the darkness around him. Truth was not the legal language of Athens, and, to her eternal shame, Socrates was condemned to die. When the sentence was pronounced, he bade farewell to those amongst whom he had laboured so long in words weighted with prophecy, through which his great love shone pure and steadfast to the end. Though unjustly 
condemned, he would accept no opportunity of flight, lest he should seem to prefer dishonour to death. On the last day, after talking long of the immortality of the soul, he bade a kind farewell to the women of his household, with Xantippe among them, and rebuked the tears of his friends. Even the messenger of death, who brought the poison, wept with the rest, and Socrates alone was unmoved, save for the sorrow of others. Taking the cup, he sprinkled a few drops in honour of the Gods, calmly drank, and then lay down to die. When Crito closed the eyes of Socrates, the Spirit of Humanity was at last freed from the bondage of tradition, and at the same time taught the true use of liberty.

\section{Sec. III.-His Method.}

The easy conversation of Socrates was the struggling speech of a new method both of inquiry and teaching.

Upon its negative side it has been called irony. Professing to know nothing, Socrates insidiously led his arrogant teacher to probe his own thoughts and discover their inconsistencies. The positive outcome is a disentangling of the confused skeins of ideas, whence knowledge was unexpectedly born. Under repeated questions is concealed a cautious development of the embryo thought. Beginning with the ordinary experience of everyday life, he compared and contrasted different instances, eliminating non-essentials, until a notion containing all the essentials of the many individual experiences was unexpectedly brought forth. To determine any question, Socrates asked those whom he met to quote instances; when a sufficient number had been obtained, he fixed a salient characteristic in one, and if by comparison it were found to be common to all, the last stage of the inquiry was to determine in what respects it needed to be augmented by others. By this method he found in the unity of a definition the invisible thread upon which the mind strings its possessions from moment to moment; by the same means he gave a touchstone for discriminating 
between the valuable and the worthless. When the definition had been established, it presented a single definite thought to the inner eye of the mind, where it lay in small bulk, easy of access and ready at any moment to afford a test to the claims of any new experience to be ranked under it or transferred to another.

\section{Sec. IV.-His Theory of Virtue.}

When by this method the possibility of grouping many diverse things under a single mental unity was recognised, it was but natural that Socrates should attach great importance to the knowing powers of the mind. But under the influence of the Sophists the starting-point was practical life, and from his own character he invariably looked at its ethical side, hence he was predisposed to connect the two together-to merge virtue in knowledge. Moreover, his conversations about life always led to the conclusion that knowledge was the line that sundered good and evil-when men have insight they are good, when they want it they are bad.

When a possible act is understood, when its relation to what is noble, lovely and true, its antecedent principles, future effects, with the full complement of means, are harmonized with the broad view of a wise man, it is known, and therefore it should be done. From this follows the apparent paradox that the man who acts wrongly, knowing the right, is better than he who is ignorant; for with the latter knowledge, and therefore virtue, is missing; with the former action in its blindness has been but temporarily incited to rebel against the leadership of knowledge.

The proposition that virtue is knowledge has two consequences. In theory, from the unity of knowledge, it follows that Virtue is One ; in practice, since knowledge can be taught, Virtue (as knowledge) is itself teachable.

The question next arises, 'Why should we be virtuous?' or, in the theory of Socrates, "Why should we act from knowledge rather than without it?' This question he never answered fully, or, rather, it was answered only popularly. We should 
act with knowledge because action waits on knowledge, because happiness rewards the good 'and misery haunts the wicked, because the State commands us and the unwritten laws of custom and society all but compel us.

Thus, in the only sphere to which Socrates himself applied his method, he was able to begin a theory of conduct and morality; at the same time, like many other discoverers, he failed to realize the importance of his work, or advance it beyond a solid foundation. The building remained for others to complete, and, when the work is ended, for enlightened humanity to inhabit.

Sec. V.-The Lesser Disciples of Socrates.

(a) The Tendency of His Followers.--Socrates left but a life behind him. He wrote nothing, and his philosophy is mainly culled from the accounts of Xenophon and what criticism has separated from Plato's own opinions in his dialogues. By Plato alone his life was glorified and his method understood and completed. From his many-sided personality others took what their nature was able to receive. Antisthenes exaggerated and caricatured the freedom from desires that ennobled the life of his master. Aristippus, finding that the impetus towards virtue, according to Socrates, was Happiness, explained virtue as pleasure. Euclides missed the true but hidden basis of the fragmentary Socratic philosophy, and supplied it from another system. Followers gathered round each of the three, and soon there grew up three schools, each professing to teach the philosophy of Socrates.

(b) Aristippus and The Cynics.-The moderation of the master became the excess of the pupil. Self-control was advocated by Socrates, and Aristippus saw no other side to his character. The fine humanity of Socrates was lost, and instead of it was substituted an ideal of the renunciation of every gratification and every desire. Even the longing for knowledge was to be stifled, and therefore virtue was not knowledge, but asceticism. 
Those who had lost or forfeited every claim to enjoyment joined Aristippus, who now numbered the remarkable Diogenes of Sinope amongst his followers. They were called Cynics, either from their meeting-place in the Cynosarges, or their miserable life 'like dogs ' (xvvıós). Virtue is the sole object to be desired, Vice alone to be avoided. All else is indifferent. Labour may lead towards virtue, pleasure most likely to vice. Hence Aristippus called for 'madness before pleasure.'

Careless of all externals, surly, isolated, wandering like beggars, arrogantly renouncing all things save strength of will, we may be inclined to censure men who, seeing with Socrates the need of reform without his power to aid, gave up every enjoyment rather than gratify it against the dictates of their better nature.

(c) Antisthenes and the Cyrenaics.-Antisthenes, true to the quest for virtue originated by Socrates, concentrated his attention upon the moral problem. But his solution ignored the side of Socrates' conduct exaggerated by Aristippus, and became based upon the stimulus given to right action by happiness. Happiness, moreover, consisted in pleasure, and the main efforts of his followers were confined to the exact specification of the gratification that should be sought.

Antisthenes himself, as a capable, dexterous man of the world, gave his vote for as much positive pleasure as could be by any means procured. Round him at Cyrene were grouped those whose strong passions gave them leisure to calculate what gratification should be especially chosen. Theodorus placed pleasure, and therefore virtue, in the calmness of spirit that avoids all excess. Hegesias went further, and recommended the virtuous man to avoid both pleasure and pain, and secure a stable equilibrium of the soul in indifference to external things beyond his control. Anniceris took a wider view, and brought the pleasure-principle nearer to practical life, by teaching that pain is often the condition of pleasure, and when, in the equating of the two, sacrifices were justified by a greater gain, they should be cheerfully made. 
(d) Euclides of Megara.-The union of virtue and knowledge needed a definite support. Struck by the coincidence between the Socratic unity of virtue and the Eleatic unity of 'Being,' Euclides proclaimed the two to be identical. Thus the practical teaching of Socrates was grafted upon the theoretical philosophy of Parmenides, the Being of the one being changed to the 'Good' of the former. As with the Eleatics, the indivisible unity is Perfection, its changeful manifestations imperfection. The sole object of desire should be the knowledge of perfection or the Good by the clear eye of reason. The many pursuits of men are therefore to be avoided.

Euclides was followed by dialecticians, as Parmenides was succeeded by Zeno. Their destructive arguments could add nothing to their barren doctrine, and the Megarians were in part the originators of Scepticism, as the Cynics laid the foundation of Stoicism and the Cyrenaics of Epicureanism.

\section{CHAPTER II.}

PLATO.

Sec. I.-The Life of Plato.

OF the followers of Socrates, only one was able to understand and perfect his philosophy, and it is a strange coincidence that the beginning of the master's teaching may be assigned to nearly the same date as the birth of his true successor. In the year 427 B.c., amid the disasters of Athens, a son was born of an illustrious house and named Aristocles. Later he was known as Plato, the 'broad-shouldered' or 'broad-browed,' and we can well imagine that the reverence of his followers adopted the latter title, by which his personality was severed from his family to become the property of the world. In his young manhood the influence of the Sophists suggested doubts that turned him from public life to study, and when he was twenty 
he joined Socrates, whom he followed through the last eight years of teaching that closed in the tragic trial scene and judicial murder.

After the death of his master, Plato travelled for many years, visiting the disciples of Socrates at Megara and Cyrene. Afterwards he wandered to Egypt and Lower Italy, where he found Pythagoreanism revived after the persecutions of the fifth century. From the Megarians he learnt the need of supplementing the doctrine of Socrates, and his contact with the Pythagoreans urged him to bring Philosophy nearer to practical life. The occasion for fitting theory to practice presented itself upon his visit to the court of Dionysius the Elder in Sicily, but philosophical theories of Government met with scant favour from the despot, and Plato was sold as a slave and ransomed by Anniceris, the Cyrenaic. Hoping still, he returned at the invitation of his kinsman Dion, when the younger Dionysius had succeeded to the throne, only to meet fresh rebuffs and new dangers.

After the first of his three visits to Sicily, Plato formally opened a 'School,' known as the Academy, where, in cloistered silence, under the shade of lofty trees, and in the presence of the sculptured effigies of gods and god-like mortals, he unfolded the sublime theory that, struggling with the problems of every department of life, endeavoured to subdue them all by a single philosophical principle. Those who remembered Socrates and new seekers after truth flocked around him-even women, it has been asserted, in the attire of men-all of whom revered the man who, by travel and study, had gathered together and reconciled the best thoughts upon the secrets of the soul and mysteries of the world. Thus, teaching, writing, or walking apart in silent meditation, he spent the afternoon and evening of life, till death came to him like a gentle sleep in his eightieth year (347 B.c.). 


\section{Sec. II.-His Inner Development.}

The life of Plato is marked by three main stages-he was first a learner, then in meeting other philosophies a critic who himself gained by the contact, last of all a teacher.

From Socrates he learnt the necessity of certainty instead of doubt, the importance of morality, and the new method of philosophic inquiry. But, to carry on the campaign against scepticism, more was needed than the mere generalizations of his predecessor. For if man be but a mere shape of the universal vicissitude, the definition or thought so hardly won from his experiences must share the uncertainty upon which they are founded. While still under the immediate influence of Socrates, Plato began to fix the definition as something permanent and above the changeful states from which it is apparently collected. Gradually the conception of virtue advanced from summation in a single thought to the existence of it. This inner progress gave birth to a corresponding change in the outward expression of philosophical teaching. The individual conversations of Socrates with living persons were replaced by the dramatized dialogues of Plato, whose opinions are enforced by the leading personages who held them and submitted to the ruling of the idealized Socrates. As the dialogues were written during the greater portion of the thinking activity of Plato, so they exhibit the same progress that marks his inner life.

During his travels the growth of other principles irradiated the possibilities and limitations of his younger work. The yet unsolved antithesis of Being and Becoming or Change, came into rude contact with his growing theory. If virtue is knowledge garnered from the field of changing life, how can the harvest be fully secured? The faculty by which man raises himself above the stream of change by binding many states under a single thought is powerless to grant a permanence that is not his to give. Heraclitus had proved, all too clearly, that 
life and the world are both hurried on without ceasing by the unalterable law of Change. Behind his changeful universe the Being of the Eleatics stands firmly fixed in a moveless calm. Each was set in mutual exclusion at the opposite poles of philosophical speculation, and there appeared no possibility of bridging the gulf. Yet Plato felt the attempt must be made, for the world in its change was an undeniable fact; but if there were no Being, if nothing were permanent, Philosophy, Science and Knowledge were alike but empty dreams. The influence of Socrates moved his pupil to endeavour to cross the gulf, while his own independent study proved a sure pilot. Plato saw clearly, what Socrates dimly guessed, that in the generalization of changing individual instances under a single thought, the mind by its activity had passed from the fleeting field of sense to the still world of reason. Hence 'Becoming' and 'Being' can be reconciled, for the former was the world of Heraclitus, the latter that of the Eleatics. Before opposed, as each claiming sole right to the same world, Plato limited and defined the sphere of each. Sense was fitted but to deal with what was plural and fleeting-to it belonged the world of Change : Reason rested in the peace of changeless unity; by it we rise to abstract Being. The definition of Socrates thus became invested with the higher order of Being, and in its new character it became the Idea, the eternal prototype of every class of concrete existence. Each Idea possessed the lofty attributes of Eleatic Being, while in their plurality they offered an opportunity of reconciling the previous antithesis of the One and the Many, for each was one with many beside it ; but if the line of demarcation be drawn elsewhere, the Idea, which was one before, has become a component part of the many. Beyond and above the fever of life there is the divine world of Ideas that gives light to our darkness and fixity to vicissitude. Its symmetry and beauty console us for the broken dreams of loveliness we may sometimes enjoy, and inspire the soul to pant onwards to the higher destiny that awaits it when released from bondage here. 
When Plato began to teach, the sublime ideal of a mortal winning the secrets of immortality* caused him to trace out and establish the Ideas in every department of thought and life. In the Supreme Good, the highest goal of the individual man, in the question of his immortality, in the State, and in the growth of the universe, the Ideas will be found establishing fixity and order.

\section{Sec. III.-The Dialectic or Theory of Ideas.}

Underlying all application of the Ideas is the ground of their existence and their various characteristics. The science establishing these features Plato named 'Dialectic,' marking the meeting-ground of the imaginary dialogues of philosophers instead of the Socratic conversations of everyday life.

Protagoras maintained that 'Man is the measure of all things,' and the standard-man could but measure through his sensations. 'If this be so,' Plato replies, ' if Sense be the sole avenue to Knowledge, it inevitably leads to destruction.' For any animal, no matter how low in the scale of creation, that has feeling, is equally the criterion of 'all things'! Moreover, Protagoras has left his theory without defence, for if anyone dislikes it, such dislike, as a feeling, is therefore correct ; and, thus, he is condemned by the very tribunal he had himself set up, and to which he has appealed. Not only is it impossible for Sense to give Knowledge, but Sense itself would disappear were the theory of Protagoras true. For in the dictum there is a reciprocity between Man and the Universe, but as it maintains all things are in a continuous eddy of change, hence they elude our senses, and sense-perception would be an impossibility. From these and other considerations it follows that Sense alone cannot lead us to Knowledge.

Neither can the way to truth be sought through the rude conviction or general consent of mankind. + For it may be

* The "E $\rho \omega s$ of the 'Phædrus' and 'Banquet.' $\quad+\delta o ́ \xi \alpha$. 
true or false, and even when true it may be produced by the artifice of a cunning rhetorician, thus being a blind impulse midway between knowledge and ignorance.

But besides Sense and instinctive conviction* there only remains the highest exercise of the mind in Thought, and here the source of knowledge must be found; for it is only by the exercise of Reason that we can raise ourselves above the struggle for life, between what was and what will be to that which eternally $i s$. It is the function and privilege of Reason to grasp pure Being, above the sphere of change, where broken shapes are ever mocking the dim eyes and ears of Sense.

By Reason we are translated to the world of the Ideas, each eternally one, unalterable; each the prototype and cause of the many changeful individuals (in the world of sense) that we rank under a common class, which owes its few traces of stability to the eternal archetype that overshadows it from a higher world. Though each self-complete, the Ideas form a hierarchy in themselves, ranked in steady files, leading by gentle transitions to those above and those below. At the apex is the Idea of Perfection, or the Good that like the sun originates and transmits light to all beneath its influence. The Good is God, the supreme Idea, and the very crown of 'Being.'

\section{Sec. IV.-The Universe and Man.}

(a) The Formation of the Universe. - The world of Ideas, established in stable equilibrium and crowned by Perfection, gives the clue for unravelling the riddle of the fleeting life of Change around us. The order and fixity of the Idea is broken up by another world, as much below, as the Ideas are above the region of sense. Opposed to the flawless Being of the Ideas is the lawless nothingness of Chaos, and the life of Change we lead is the result of both, deriving its broken order from the Idea and a half-resisted indefiniteness from 
Chaos. Thus the whole universe in its endless state of Becoming is a middle state between the opposite states of pure Being in the Ideas and the utter absence of Being in Chaos.

How have these two contradictory states of Being and nonBeing been coupled together to form the universe, for each is thoroughly isolated from the other? The medium to harmonize the antithesis Plato found in a principle which he named the 'world-soul,' from its analogy to the soul of man that in its own life can soar to the world of Ideas, though usually fettered by change. So the world-soul is a limit both to the formlessness of Chaos and the lonely 'Being' of the Ideas. It is the medium to connect the individuality of this formlessness with the universality of the Idea, and the unity to the Idea with Plurality. Thus it is the principle for ordering and combining the primitive constituents of all things.

The forming process is clothed by Plato as an allegory. The former of the world (Demiurgus) united Ideas with Chaos, and from both arose the 'soul of the world.' $\mathrm{He}$ then arranged it, as an ideal framework, throughout the whole space to be occupied by the universe. This sphere, ordered by world-soul, was divided into spaces, first for the fixed stars, then for the orbits of the planets, and last of all at the centre for the world itself. Round this centre the four elements are evolved from Chaos, and from them our world is formed, and completed by the creation of organized life.

Thus Chaos was transformed to Beauty and order, for, as the whole creation was directed by the Idea of Perfection, the huge living universe is the highest product of Divine art. By the soul that inspires it the world of Ideas gives it a part of the perfection that belongs pre-eminently to itself. Therefore, it is one, orbed in a perfect sphere, rotating silently in a circle like the progress of Reason itself, unchanged in its outward form while bearing within it the many changes of the life of man. 
(b) Man.-Like its prototype, the great world-soul, the soul of man is the meeting-ground of the ideal and material. Upon its higher side it is a citizen of the Divine state of the Ideas, its true home, and the goal of its loftiest aspirations. But the soul has also its lower side. It is fettered to the body, and hence becomes the unwilling vassal of change, subjected to the fluctuations and troubles of sense, thus uniting the opposite attributes of Heaven and earth, of the Divine and bestial. Therefore, the soul looks with double face to the worlds of Being in the Ideas through Reason, and of Becoming through Sense. In its former capacity it is rational ( tion of these opposite parts is effected by the Heart ( $\left.\theta u \mu_{0}^{\prime} s\right)$, which, like the instinctive conviction* of the Dialectics, is the medium, partaking in part of the nobility of Reason, but from its blindness and want of insight also linked with the sensitive life of the body.

How the soul forfeited its divinity in the contemplation of the perfection of the ideal world is symbolically explained by a philosophic myth. The soul is like a chariot, horsed by the impulses of its parts. When the winged steeds move in the same direction and under due control they bear the soul to the Ideal world, beautiful beyond the dreams of art or the imagination of poetry. Such is the existence of the gods. Other chariots less skilfully driven touch the higher world but to sigh for a fuller enjoyment of it, and then are dragged by the greedy horse of the desires to earth. Here they are imprisoned in bodies, and enslaved by the lusts that first drew them from heaven. Yet the Divine element is never wholly subdued. In calmer moments reason whispers faintly of the earlier joyous career in the morning of existence, when the soul-chariot passed Idea after Idea, each containing some hidden secret of the world. The voice of Reason tells of the lost home from which it has been exiled, recalling its perfect beauty and 
harmony* from the stray broken shapes it sometimes recognises here.

Reason, too, has a promise for the aspiring soul. When the narcotic of sense that dulls her inner eyes is overcome, her nobility is understood, and from it arises the longing for a higher future state, where her prophetic voice will be vindicated, and the secrets, that mock her now, will be revealed. For such as deserve it, death will be the bursting of the prison of sense-to those who fail, a doom condemning them to pass through new bodies till they become purified from sense, and complete their expiation.

\section{Sec. V.-Ethics and the State.}

(a) The Supreme Object for Action.-When the ideal promised to the soul is so lofty, it becomes its duty to endeavour to realize it. The end of all action must be to escape the tyranny of sense, and rise to the higher world from which the soul has come, and to which it must win its return. The will must emancipate itself from the unhallowed cravings of sense, that ever bind it faster to earth, and strive to follow the indications of the Idea that struggle though the few short lulls in the storm of change. As sense degrades, it must be crushed to make way for the elevating powers of reason, that point to Philosophy as the sole ladder to mount from the lower to a higher life. By thus turning inwards the soul regains something of its pristine freedom, and power to raise itself above the alien desires that would still bind it to earth, while as it gains in strength it reads more clearly the promises of the future.

In placing the supreme object for the will in the cultivation of Philosophy, Plato was opposed to the Cynics on one side, and the Sophists followed by the Cyrenaics on the other.

The Sophists and Cyrenaics especially reversed the order upon which Plato insists. Philosophy with them was useless, 
and Pleasure the sole object of desire. By the Dialectic Philosophy was reinstated, and besides the many imperfections shared by pleasure with the whole of sense, it can give neither harmony to life nor worth to the soul; and, moreover, like the kindred theory that builds knowledge upon the same foundation, the undue elevation of feeling destroys its consistency, for if it be the guide of life, its contrary pain verges so close upon it that a distinction is practically impossible.

The faint-hearted desertion of Philosophy by the Cynics is sternly reproved by Plato. While exposing the seductions of Pleasure, he held that the eradication of the higher delights of knowledge was equally a false reading of the moral voice of nature. The Beauty seen by reason is essential to the harmony of life, and from it flow the innocent joys of spiritual pleasure that aid the mind that struggles upwards towards virtue. The exact place to be assigned to lower pleasure is but vaguely indicated. Knowledge and Philosophy are the presiding and guiding elements in the ideal joy; beside them pleasure is sometimes ranked as aiding in the rounded completeness of life, sometimes as the ignis fatuus that leads reason astray, and breaks the unity. Such pleasures as knowledge approves, and that aid in its development, may advantageously be sought, and, when directed by Philosophy, aid in the growth of a life symmetrically arranged, and balanced for its flight from earth. The Beauty given by art must be chastened before it can receive the sanction of Reason. Like our instinctive convictions, it wants the insight of the true beauty seen by the philosopher in the ideal world. The 'fine frenzy' of the poet or artist must be replaced by the conscious appreciation of the sublime order and harmony that is immovably fixed above us, which transcends our dreams of loveliness as much as the Idea the shattered image that we gather from reflection upon the shifting field of change, or from the faint recollection of our lost higher life.* To rise from its degradation Beauty must be 
separated from every trait that panders to our lower nature, and enrolled in the service of the Idea of Perfection, from which it had its birth, and by which alone it can realize its mission.

(b) The Doctrine of Individual Virtue.-The following of the 'Supreme Good' is virtue.

From one point of view it is, as Socrates taught, 'Knowledge One, and Teachable '; but as it becomes based upon the theory of Ideas, Plato in his later works sometimes speaks of many virtues, thus apparently contradicting Socrates by asserting that Virtue is many. By right of the Idea, Virtue is one in its characteristics, but plural in its manifestation.

As the soul has several parts, so an appropriate phase of virtue belongs to each. The right exercise of Reason is Wisdom. When the heart supports the decision of Reason, arming itself rightly against the wiles of pleasure and the menaces of pain, it is brave, and hence its virtue is Bravery or Fortitude. When the senses are maintained in due control they give rise to Temperance. To obtain complete harmony of the three parts, and the fusion of their strength in the pursuit of what is best, is the duty of Justice.

(c) Collective Virtue in the State.-When the horses of the individual Soul have been duly broken and harnessed, it only remains to yoke the larger chariot of the State for a similar journey from sense to the Ideal world. The Idea of the State is summarized in the larger Justice that unites its members, and as Justice guides the individual virtues of a single man, so the giant Justice of the State binds up the virtues of collected groups of citizens. As there are three parts in a single man, each with its appropriate virtue, there are three separate groupings of the members of the commonwealth, each of which must nurture the virtue it is best fitted to produce.

The ideal State finds its reason in the Rulers, who legislate, and manifest Wisdom. The Heart of the State, midway 
between reason and sense, is the class of Warriors to ward off all hurt. The senses are paralleled by the Workers, who provide for the wants of all, and from them Temperance is demanded. When all classes work well, each in its sphere, the law of the State is satisfied, and, as a whole, it exhibits Justice.

Where the life of the State consists in its rigorous submission to the Idea, all that is individual or personal is annihilated. The goal of the Ideal is the production of a body of men fused into a single unity. By the alchemy of the Idea all that any man would claim as his exclusive property is transmuted into the possession of the State, in which all rights are centred. Money, self-culture, amusements, even domestic life, exist not for one but for the whole. Everything must be shared alikecommon weal, common woe, and common wealth.

There is no scope for individual effort or individual choice. Marriage was abolished, and children were born and educated as the Wisdom of the Rulers ordained. In the two higher classes the healthy infants were consigned to the State nurses and teachers, from whose hands they passed at a stated age to be instructed in mathematical sciences. From thirty to thirtyfive their education was completed by the study of dialectics, and then they were tried in discharge of the duties of the Warriors. Those who proved themselves fittest at fifty were permitted to devote themselves to Philosophy, alternated with periodic control of the State.

Throughout the whole scheme in the education and life work of its members the State is the engine for establishing the law and fixity of the Idea in the minutest details of public life, and it thus fitly closes the philosophy of Plato, marking by its comprehensive swoop from the most abstract theory to practice the strong influence of the teaching and self-devotion of Socrates. 
Sec. VI.-Plato's Successors in the Old Academy.

The settled college of the Academy continued a recognised society for philosophic research after the death of Plato. But with the exception of Aristotle the pupils of Plato did little to extend the deeper principles of his theory. As a body they aimed rather at exposition than discovery, and any additions made to the theory tended to impair its unity and consistency.

In his later teaching Plato had largely adopted the symbolism of the number-theory of the Pythagoreans, and Speusippus, his nephew, who succeeded him, endeavoured to reconcile the characteristics of the Ideas with the 'Numbers' of the older theory. In this he was followed by Xenocrates, who was the first to divide Plato's philosophy into Dialectics, Physics, and Ethics. As the learning of the school grew its research declined; even in the adoption of Pythagoreanism the fresh features added belong more to the life of the body than its philosophy. Polemo is chiefly remembered as a moral philosopher. His pupil Crantor was the first commentator of Plato. After Polemo, Crates became the head of the school, and with his successor, Arcesilaus, the school entered upon a new period of its history.

\section{CHAPTER III.}

ARISTOTLE.

Sec. I.-His Life.

PLATo alone of the disciples of Socrates was able to carry on the growth of the new theory, and his own philosophical insight was understood by a single follower, Aristotle.

Fifteen years after the death of Socrates, while Plato was travelling in Italy and Sicily, a son was born to Nicomachus, 
the physician of Amyntas, King of Macedonia, at Stagira in Thrace (B.c. 384). This child was named Aristotle. His parents died while he was still young, and his education was undertaken by Proxenus, who caused him to be instructed in all the physical knowledge of the time. When Aristotle was seventeen his guardian died, and, eager for knowledge, he set out for Athens, where he arrived as Plato was starting for his last journey to Sicily. Disappointed in his desire to join the crowd of searchers after wisdom, Aristotle devoted his young enthusiasm to the pursuit of those who remembered the wisdom of Socrates, and the acquisition of the writings of the earlier thinkers, from which he gathered the information that enabled him in later life to found the history of Philosophy.

When Plato returned, Aristotle became one of the most diligent pupils of the Academy. With restless impetuosity he entered new fields of knowledge beneath the soaring genius of Plato. During the twenty years of his spiritual apprenticeship he gradually mastered, and then began to rearrange, the Theory of Ideas, and from this fact, it is probable, arise the accounts of the dissensions between master and scholar.

After Plato's death Aristotle migrated to Atarneus in Mysia, where he married a relation of Hermias, the prince of the state. Subsequently, from his second marriage with Herpyllis, he had a son who was named Nicomachus, after his grandfather. From Asia Minor Aristotle returned to Athens, where he opened a school of Rhetoric.

But his teaching at Athens was closed by the summons of Philip to undertake the training of the spirited youth of Alexander, that chafed at the blind obedience demanded by ordinary teaching. The ideal instruction of statesmen by philosophers that Plato asked was fraught with gain to Alexander, and right royally recompensed by his father, who, it is reported, rebuilt Stagira in honour of Aristotle.

When Alexander's philosophical pupilage expanded to the more trying discipline of conquest, Aristotle returned to 
Athens, and opened a new school in the Lyceum. The Cynosarges was already occupied by the snarling Cynics, the shaded Academy sheltered the lofty Ideals of the Platonists, and Aristotle's impetuous energy gave his followers the title 'Peripatetics,' or Walking Philosophers, from his habit of restlessly pacing up and down while lecturing. In the morning he taught more advanced pupils, while the evenings were devoted to popular discourses to larger audiences. His quiet academic life was rudely broken by political charges brought against him after the death of Alexander, and being accused of blasphemy by the Athenians, he went to Chalcis, lest, as he expressed it, his fellow-citizens should twice outrage philosophy. In retirement he died in the year 322 в.c.

\section{Sec. II.-His Historical Position.}

Aristotle is the last of the three great names associated with the Socratic period. The philosophic importance of the universal element in man had been humbly advocated by Socrates and sealed by his life. In Plato the common and consciously generalized thought had received the same permanence in metaphysics that the memory of the discoverer won from the reverent souls of his disciples, and the Ideas enthroned as Being lent brief gleams of fixity to the changing world we see around us.

The problem confronting Aristotle was the necessity of pruning away some of the superfluous scaffolding and inner contradictions that disfigured the Platonic system of the Universe. From the conflict of Being in the Ideas and the negation of Being in Chaos arose the world of Becoming. But what principle had Plato proved for the thorough union of contraries that were opposed in every characteristic? The immutable phalanx of Ideas possessed no force to subjugate an alien camp that was sundered from them by the gulf of contradiction that baffles the power of the mind. As Plato granted 
causation to the Ideas, their permanence slipped away, and hence he looks more to their abstract Being than the power he sometimes grudgingly offers them of coalescing with the formlessness they are to order and direct. Thus, in the Platonic account of the birth of the Universe, the collocation of Ideas and Chaos is effected by the mythical Iemiurgus that is extrinsic to both.

To rid the world of this mythical power, which is the despair of Philosophy, Aristotle was forced to revise the fundamental presuppositions of Plato. If the older philosopher centred his system in an ideal world above, with its correlate in the nothingness below our own, his pupil, on the contrary, established himself in the everyday life of Change that Plato abandoned as the product of an antithesis. Thus, as the Being of Parmenides is exalted in the Platonic Idea, the Change of Heraclitus returns from purification in the hands of Aristotle.

Change, Aristotle discovered, is something more than the play of opposed states that alternate between what is and what is not. In all mutation there is progress and development-an upward progress, not the pendulum-swing from limit to limit. Thus the world around us is marked by ceaseless growth, rising by graduated scales-not, as Plato taught, graduated Ideas, but graduated grouth. When any point is reached, it has become the condition for that immediately above it, and, though not yet promoted, in the general process of development its possibilities must finally become actualities. In the scale of progressive change there must be a first step and a final result. At the lowest end there is an absolute possibility, ready to grow to any or every actuality; upon the other side there is the absolute actuality, the final outcome of the last elimination of possibility by progress. Thus, it will be seen, the primary antithesis of Plato is evolved as the last result of the principles of Aristotle. 
Sec. III.-Aristotle's Philosophy-(A) Metaphysics.

(a) Logic.-Like many other branches of knowledge, Logic owes its foundation to Aristotle. 'Though he never consciously divided it from the portion of his work that afterwards became known as Metaphysics, it was the general summary of his method of search and inquiry.

The main features of modern formal logic were fully established by Aristotle, so that Kant, writing after an interval of two thousand years, has said that the science has neither advanced nor receded by a single step. Thought mounts upward by the spiral stair of the syllogism, which contains its own clear laws of legitimate progression. In a complete science the lowest step rests upon actual experience, rising through connected and intermediary grades to the highest, which is without presupposition. The former is grasped by the experience of everyday life, the latter by the intuition of Reason (vo $\tilde{s}_{5}$. To rise from the first step given us by the senses to the next, which must be a general proposition, is achieved by a process of generalization, similar to the Socratic inquiry, which Aristotle named Induction. By comparison of individual instances, the leading attributes are abstracted from them and united in a single thought or concept. A higher concept is next formed, and it becomes a higher step, and the mind passes from one to the other upwards to gain the final principle that crowns the tower, whence it can overlook the whole field of the science under investigation. But the collection of individual instances is a toilsome task beyond the energy of the unaided student, and he is forced to accept the experiences of others upon their authority, and from these he must generalize the definition or distinguishing concept of each class as he passes it in his review. But as the method was new, and the accuracy of observation necessary had never been cultivated by those whose records Aristotle was forced to accept, we are compelled to admit the justice of the pathetic sentence with 
which he closes his work, pointing out his isolation as a discoverer without predecessors or helpers.

The general method of discovery is therefore twofold. The tower for the circuitous upward movement of the mind is built of the generalization of facts collected by Induction, and the stair is fitted in by the Syllogism. Though the sciences to be completed differ in every part, the method is invariably the same, and as the mind mounts stages will be found that exhibit constant marks. Led by this clue, Aristotle divided all concepts used in the syllogism into ten 'main classes,' which were named Categories. They are substance, quantity, quality, relation, where, when, position, possession, activity, passivity. ${ }^{*}$

(b) Metaphysics. - The name 'Metaphysics' was not given to any part of his work by Aristotle himself, but was used by commentators to indicate the classification of the works dealing with the most abstract sciences as occurring 'after the Physics'

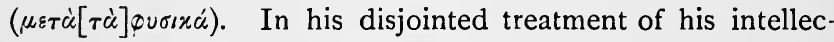
tual work, Aristotle was in the habit of devoting a separate monograph to the study upon which he was engaged at the moment, and in so doing he found a series of related sciences, each dealing with a special phase of concrete existence. To supply their foundation, it was necessary to investigate the pure basis of Being that was common to all, and that provided the proof of the elementary suppositions upon which the other sciences rested.

I. Aristotle's Critique of the Platonic Ideas.Aristotle agreed with Plato that there can be no knowledge to be gathered from the mere fleeting phantasms of Change and sense. The quest must be pushed to the higher region of permanent Being that is reached but by thought.

Here Aristotle parts company with Plato, for he cannot accept the motionless world of Ideas. For the Idea must either be the same or not the same as the sensuous things from which it originates. If it be the same, it is obviously a useless

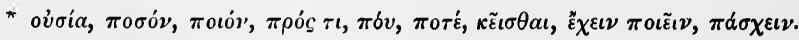


duplication of the original problem. If, on the other hand, it be not the same, its lonely isolation sunders it from all possibility of explaining the changing things from which it was gathered, and for whose existence it was created to account. Thus, when confronted with the world, the Idea cannot justify itself, and, besides, it is powerless either to produce or control mutation. In the Idea things of experience merge their qualities, and these are petrified into everlasting Being. The Idea, therefore, contains universal attributes under its own indivisible unity. But can the characteristics of an object be severed from it? Moreover, when torn from their roots, can they with impunity be transplanted to an alien region? From the world of Being the Idea cannot look back upon the world of sense, for in its migration it has been stripped of all that might promise safety of return. The participation of the Ideal type and the copy in the lower world is therefore but an illusion. Hence, upon the whole, the qualities abstracted from the things of experience have no claim to arrogate an existence in a higher world than that to which they were born.

2. FORM AND MATTER. - Though the generalized qualities of a class had been raised by Plato beyond their proper rank, they yet take a higher place than the perishing individuals from which they have been collected. But the important consideration is not the elevation of the one nor the depression of the other, but the relation between the two. The Idea, shorn of its pretence, becomes what is fixed in every class. The indefiniteness of a large number of individuals is clearly expressed in the defining thought that embodies their main features. This thought or concept is thus the permanent element in a throng of single things we rank together-the iron band that ties the class together. Neither can be separated. Without the binding thought or definition, the members of the class would elude observation, and without the individuals the iron band would sink out of sight in the void. The invariable binding element is Form ( $\left.\varepsilon^{i} \delta \circ \xi\right)$, the variable bound members are Matter $(\dot{i} \lambda \cdot \eta)$. 
Matter is the rude material to be worked up and realized in the more complete result; as the marble block must receive the binding impress of the artist's thought, so Matter everywhere is the obedient recipient of Form. The finished marble statue contains Form and Matter in equipoise ; the chiselled realization of the sculptor's idea is the Form that moulds the marble Matter.

But the statue cannot stand alone. As a part of the decoration of temple or home, it is Matter to be again worked into a larger whole. Thus the principle is universal in its application. Nothing can be isolated; everything must take its place in a graduated scale, in which each member is Form to those below and Matter to those above.

Change is therefore no longer a riddle, but the necessary condition of the endless progress from Matter to Form. The whole world is endless movement, and every phase of causation looks on the one side to Matter, on the other to Form.

Matter is thus the possibility of the appropriate realization, and in the process of change Matter is therefore always potential until its end is realized, when it blossoms into actuality.

Moreover, the endless growth of potentiality into actuality must start from an absolutely formless Matter and press on to an absolutely matterless Form. The formless Matter is adapted to receive any Form ; it is complete potentiality, utterly undetermined, and, in severance from Form, the great negation. Under the determination of Form, potentiality gradually approaches nearer and nearer to actuality, each successive product lessening the factor of Matter and increasing the factor of Form, till the Divine matterless Form completes the series in the full purity of the Deity.

God, as free from Matter, is One, for Matter is the realm of plurality : He is the unmoved cause of motion, for Matter is the field of derivative movement : $\mathrm{He}$ is the Supreme Intelligence, for Matter is the negation knowledge. As the sum of actuality, His activity consists in thought-a thought, moreover, 
that must be self-contemplative, otherwise $\mathrm{He}$ would degrade Himself by commerce with the lower range of potentiality. Hence the sphere of Divine knowledge is self-contained; in the sublime exercise of omniscience the process of knowing is identical with the known, the infinity of Godhead merges thought and thinking, and therefore God is the very 'thought

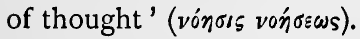

\section{Sec. IV.-(B) Physics.}

(a) The Universe. - The opposition of Plato and Aristotle is most clearly marked in their treatment of Physics. From the Ideal point of view, the clamorous world of Becoming and Change could claim but little place in a stable state of Being whose order was the admiration of the Philosopher. Aristotle, on the contrary, saw beneath the vagaries of change the fixity of a settled purpose of development, and, finding the permanence that Philosophy demands before him in nature, he had no incentive to wander abroad from it. Change, he believed, advanced through successive potentialities with faltering steps, but unshaken purpose, to its physical actuality in man. Potentiality was invariably directed to form a perfect universe for the support of life, and life advanced through all its grades to culminate in man.

Movement is the prime requisite for the development of the potential, and hence motion is the guide that leads inanimate existence through its stages. Motion is measured by time and given room for its progression by Space.

The summit of existence is occupied by God, the unmoved Cause of all other motion. In the globe of the universe the region of the fixed stars borrows its motion from Deity moving in the perfection of the circle round the outer orb and nearest God. Below the stellar cycle the planets revolve in their orbits, guided by immortal beings less perfect than the wider range of those beyond. Round the centre is the earth, less 
perfect than the rest, but still with the impulse towards perfection derived from the growth and decay engendered by the light of the sun, that by its change promises movement and progress.

(b) The Earth.-In the ebb and flow of existence on the Earth, the lowest place is taken by inanimate things produced by the combination of the elements. Without life their actuality is attained when they reach a position adapted to them.

The line between inanimate and animate existences is sharply drawn by 'soul,' or life, which is the form and energy of an organized body.

In plants, life manifests itself in the lowly guise of a faculty of nourishment and reproduction. The life of animals possesses the additional element of feeling, and, in its higher forms, movement. In Man reason is united to plant-life and animallife.

(c) Man.-The efforts of nature are crowned by the production of man. Even in his shape, upright position, pure blood, large brain, and power of speech, he overtops the lower kinds of life. As the realization of nature's energy he possesses the lower phases of life. He can nourish himself, move and feel. Dowered with many senses, each contributes its special accurate quota towards the knowing of the object to which they are related.

The sensations monopolized by each sense are brought to a common mart of exchange named the Common Sense,* where they become converted into memories and images. To link images with thoughts is the function of a higher life that belongs to man alone.

Reason (voũs) distinguishes humanity from the sense-life of the brute, and communicates to Man his germ of Divinity. Since the life shared with other animals is the Form of the body, it perishes with it ; but Reason in its indivisible simple unity lodges with us but for a time, and lives beyond the death of the body. 
The Reason itself has two sides. To meet the images of the Common Sense, it is passive, and gradually leads to knowledge. But behind the passivity there is a sublime activity, the true voũs, that grasps the highest principles, and sees with intuitive certainty the mysteries that are beyond and above proof.

When the desires clamour for gratification, it is the function of Reason, in its freedom, to turn from theory to practice, and decide the best means and end for action. Thus the practical

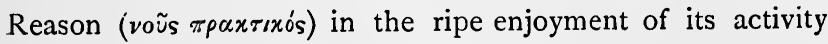
becomes the guide of action and hand-maiden of virtue.

\section{Sec. V.-(C) Ethics.}

(a) The Summum Bonum.-Man in the exercise of his activity invariably acts with an end in view. When it is attained another looms before him, and in the endless ascent from hope to hope he longs for a final end that will contain all others, and whose gain will satisfy his cravings. The testimony alike of experience, tradition, and the whole individual actions of mankind proves that the world's desire is Happiness.

The question of supreme moment is, What is Happiness? As the perfection of life and the gratification of every desire, it must be the realization of man's possibilities to the full. It is the giant stride of progress that perfects every part of his nature, and garners his every field of possibility into one full actuality.

As sensitive beings, the wants we share with other animals must be allayed. Health, the satisfaction of bodily wants, children, friends, competent wealth, and social influence, form negative but indispensable conditions of Happiness. Though the want of any or all of these fails to bend the wise man's soul to misery, it can rob him of the actualization of his nature, and therefore of Happiness. 
After providing for lower wants and lesser cares, there is still man's special possession in Reason to be considered. As it is by Reason that man overtops those below him in the scale of existence, it is only by the perfect satisfaction of Reason's claims that he can gain Happiness. But Reason is the guide of action, and its rigorous demands are only granted when Action follows Reason, when in their union Virtue is the mainspring of life's undivided energy. Therefore Happiness consists in the perfect activity of right action, whose sphere is a life devoid of lower cares. Hence Happiness is a ' perfect activity in a perfect life.'

(b) Virtue.-When virtue is the main element in the Happiness that all desire, the attributes of virtue also must be definitely ascertained. Virtue is the application of Reason to life, and as Reason holds the scales, the virtue in any combination of circumstances will be a mean between the opposite states of too little and too much. For action may end in stopping short of the goal or over-passing it, and it is only when duly meted by Reason that it gains the true result. The golden mean, moreover, differs for different persons, and it can only be ascertained for a definite individual by the full consideration of his capacities and surroundings.

Moreover, it is not enough that the mean should be sometimes attained, and sometimes overstepped. Man cannot become virtuous at a bound, but by the steady development of his capacities.* Virtue concerns the will and passions, and the will must be trained. Therefore Virtue is not knowledge (as Socrates held), nor can it be taught, for man grows in virtue by exercise, and it is only when such exercise has become habitual $\uparrow$ that a man can be called good.

Nor will Aristotle follow Socrates in the unity of virtue. Whenever the passions can be dwarfed or when they can hurry man to excess, the mean must be applied, and therefore the virtues are numbered by the main relations of life. In the

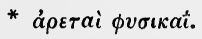

t When a "้̋ॅs is formed. 
inner hidden life of the soul, in society, in the friendly relation of man to man, in the wider connection of bodies of men in business or the State, a mean must be decided and established.

But as the mean fluctuates with the emotions of the individual and the nature of the case, how is a standard mean to be established ? Here Reason must apply its touchstone of careful tact (фpóvnoıs), elevating man above himself, by giving him a law to the will to curb his desires.

Reason, moreover, within itself contains specific virtues apart from its exercise in the control of the emotions. In these, the acme of felicity is reached in the cultivation of philosophy, the perfection both of Reason and of life.

(c) The State.-Many virtues involve the interaction of society, therefore the individual can only be fully developed by the State, and thus Ethics culminate in Politics. Moreover, man is by nature a 'political animal,' seeking the society and intercourse of his fellows.

As man finds his completed aim in Happiness, which provides his moral growth and physical well-being, so the bodies of men, united in a State, find in it a larger development and recognised legal security. Hence the aim of Aristctle's polity is not the abstract state of Plato that absorbs individual claims to secure the perfection of the whole, but the most complete development of every single man, who ranks as a citizen without prejudice to property, rights or personal ties.

In its educational function the true State must be virtuously guided. Therefore it may take three forms according to the division of virtue amongst the rulers. If one man distances all others in excellence, his government is monarchy; if the good qualities are divided amongst a few it becomes aristocracy (i.e., government of the best); if all the citizens are equal in capacity, their self-ruling is timocracy. When the basis of government is planted upon any other attribute than virtue, the State is false to its ideal. When the poor or the people 
clamour for power in a democracy, when nobles usurp position by wealth (oligarchy), or when a despot violently mounts above the rest (tyranny), Virtue has been lost sight of, and the State is a failure.

As virtue takes many forms, there can be no certain rule applied for the invariable exercise of the supreme power. As long as the growth and moral development of the citizens is the object of the State the impulse is in the right direction, however much its manifestation may be varied by circumstances.

\section{Sec. VI.-The 'Peripatetic School.'}

After the death of Aristotle his place was filled by Theophrastus, who increased the importance of the school by bequeathing it an estate. Like all others who have remained in philosophic schools, he contributed little to the development of the theory, confining himself to supplementing the positions already determined. In logic he added the propositions of Modality to those previously enumerated, and the treatment of hypothetical and disjunctive arguments to the theory of the Syllogism. His chief contribution to metaphysics was a more accurate discussion of the passive and active sides of the Reason, which, however, only made clearer the difficulties involved in the distinction. Of his other works his investigations upon the nature of plants made him the great authority upon Botany till the close of the Middle Ages.

Eudemus was a contemporary of Theophrastus, and one of the personal pupils of Aristotle. His chief contribution to the philosophy of the school lay in his Ethics, where he endeavoured to supply a common principle for the derivation of Aristotle's disjointed virtues. Aristoxenus of Tarentum had come to Aristotle from the Pythagoreans, and he introduced the treatment of music, and from it endeavoured to identify the Aristotelian Form with the older Harmony.

Strato, the 'physicist,' succeeded Theophrastus as leader of 
the school, and instead of the Deity as the first Form, he substituted an unconscious internal energy of nature.

Strato was succeeded in the leadership by Lyco, Aristo, Critolaus, Diodorus of Tyre, and Erymneus, who all united in handing down the main theory in brilliant lectures without any addition of importance. 


\section{PERIOD III.}

THE CHARACTERISTICS OF THE LAST PERIOD OF GREEK PHILOSOPHY.

As Anaxagoras closed the first and tentative period of early philosophy by the supposition of an ordering principle opposed to Chaos, so the movement originated by Socrates is rounded off by the same theory of development enunciated by Aristotle from a higher plane, with wider range and fuller application. From the continuous transition of Matter to Form, there results a final evolution of the component members that formed the basis of the last expression of the Socratic teaching.

After the death of Aristotle the germs of a larger growth lay ready, but Greece had already begun to decline, and with its fall Philosophy lost her home. As before, in the time of the Sophists, men began to turn inwards, and, in the disintegration of the State, they were compelled to find a speculative justification for the divergencies of individual aims and actions. The East had been opened to Europe by the victories of Alexander, and its luxurious repose was partly deadening to effort, partly a stimulus towards the reconciliation of the ephemeral Hellenic religion with the changeless theology of the East. Philosophy was again interrogated for a law of life and canon of belief, and now her answer was half-hearted.

When the Sophists had challenged early inquiries, the reply was given back without hesitation or delay, for Greece was animated by a vigorous political activity that, in the en- 
thusiasm of its energy, was at one with the world by practical faith and manly self-confidence. In the century separating the beginning of the teaching of Socrates from the death of Aristotle, the national life had grown old, and its faith had sunk. With the loss of freedom the old harmony of man and the world was succeeded by the discordant relation of Greece at odds with herself, a disunited people, without confidence in the present, without hope for the future.

Even in her decrepitude Hellas maintained the nobility that marked her youthful promise. In the changed life of the nation the need of reason as a guide to conduct was manfully vindicated with the varied characteristics of age. Scepticism* was opposed by the practical philosophy of the Stoics and Epicureans, as the Sophists had been met by Socrates. But the force of reason inevitably shared in the failing powers of the nation, and Stoicism and Epicureanism alike represent the moral effort of Socrates, deprived of power to regenerate mankind, and driven back from legislating for universal virtue to vindicating the power of the will over externals that cramped its exercise. Eclecticism is the duplication of the fusion of previous systems by Plato without the stimulus of national vigour that gave him the strength to bind them all under a single comprehensive system. Neo-Platonism returns to the graduated progress of Aristotle, but with a similar limitation

* Pyrrho of Elis was the first to give philosophic impression to scepticism. He was a contemporary of Aristotle and died within a few years of Theophrastus. As a student of the Megarians and a follower of Alexander's campaigns, he was one of the first to feel the collision of the East and West.

Man's great aim is Happiness. But to be happy we must know things : (i.) What things are, (ii.) how we are related to things, (iii.) and what is the result of the relation.

First, we can never know the nature of things, for we can only learn from our senses appearances, not realities. Therefore, secondly, we must always reserve our judgment ; we can never say, A is B; only, A seems to me to be $\mathrm{B}$. In the last place, since we are shut out from knowledge, it is clearly inconsistent to exert any preference for one object rather than another. Therefore Happiness consists in an entire suspension of choice, an utter impertur-

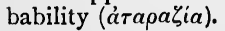


imposed by the times. By Form and Matter reason won a path from lowest to highest existence; while the later school, with restless impatience, endeavours to reach the same result by a confession of impotence in a mystic system established not by knowledge, but by the stifling of reason, and the elevation of a biased but baseless faith.

There is a large majesty in the death of a nation that demands the awe of the beholder. Its sanctity may not lightly be profaned, nor the silence that veils it broken save with reverence. In dying, Greek philosophy gained a deep prophetic earnestness that atones for its loss of scientific fulness. The mind has been recalled from the fascinating pursuit of knowledge to an intense concentration upon the inmost springs of moral action. Without hope from religion or the world the mind must resolutely face the dread enigma of the limitations that cramp its will, and decide where and how it can gain a victory over circumstance.

The Stoics and Epicureans, repeating the work of Socrates, were animated by an intense earnestness which left behind it a union of Thought and Fact, completed and finally consolidated before the end. The warfare of the remaining theories was from the first foredoomed. The patchwork of Eclecticism, and Neo-Platonism, with its deposition of reason, are the work of men whose activity was circumscribed by a sinking civilization almost setting in the darkness of the Middle Ages.

'Go honoured hence, go home, Night's childless children; here your hour is done.

Pass with the stars, and leave us with the sun."*

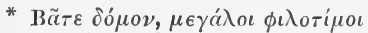

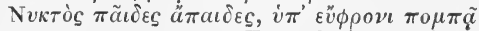

From Swinburne's 'Two Leaders.' 


\section{CHAPTER I.}

\section{A.-THE STOICS.}

\section{Sec. I.-The Philosophers of the Stoa.}

In the forefront of the teachers of the decline of Greece is Zeno of Citium. He was born a few years before the death of Plato ( 340 or 342 B.C.), and upon the loss of his property he became a student of Philosophy. From the Cynic he passed through the Megarian school, and at last joined the members of the Academy. After twenty years of study he opened a new school at the Stoa Pœcile, whence his disciples were named Stoics. After a lengthy presidency of the new sect, he put an end to his life, thereby inaugurating the principle of suicide which became fashionable amongst his followers.

Zeno was succeeded by Cleanthes, a man of great force of will, who, from want of originality, faithfully perpetuated the teaching of Zeno, whose practice he followed by voluntary death. Contemporary with Cleanthes, and also personal pupils of Zeno, are Persæus, Aristo of Chios, and Herillus of Carthage.

Cleanthes was followed by Chrysippus, the great pillar of Stoicism, who popularized the system by his numerous works, and completed its development.

The writings of the Stoics remain but in fragments, and it is difficult to distinguish the work of individual members from the more complete accounts of later authorities. The main characteristics of the Philosophers of the Stoa are an exaltation 
of virtue in brave opposition to the laxity of the life they saw around them, and a sturdy resistance to the seductions of pleasure that in the general luxury usurped the throne of right. While the whole edifice of Greek faith was crumbling in ruin, the Stoics summoned men from the selfish desire of mere safety to trust in the strength of will that was still unbroken, and that rose above the general wreck with a full consciousness of its inborn majesty. The individual disappointment that drove men formerly to don the threadbare robe of virtue, with the Cynics had now become a national grief, and the older self-sacrifice was sternly exacted by the decline of Greece. Knowledge sought for its own sake was no longer possible when the life of the people was doomed. In a freedom hurrying to bondage, the small domain of action yet unenslaved must be rigorously guarded, and knowledge of man or the world has no scope but to act as sentinel to its avenues. Hence the system of the universe that in Plato and Aristotle preceded every ethical inquiry is replaced by a mere outlined sketch that leaves free scope for moral work.

\section{Sec. II.-Logic and Physics.}

The contraction of the sphere that bounds man's mental range shuts him out from the determination of the meaning of Knowledge. The mind in its darkness waits for impressions to be made upon it, and the impressions are generalized by the understanding. But to guarantee the stability of action there must be no doubt that our thoughts are true and certain; the growing scepticism must be routed at the very outset. This the Stoics accomplished, not by rigorous proof, but by the indication of an infallible criterion that decided definitely when certainty can be predicated of any thought. When any phase of consciousness has been produced by an actual object, when it is no mere masquerading figment of the imagination, it bears an irresistible evidence with it that actually grips the 
mind and fills it with an overpowering conviction of certainty

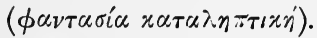

When knowledge is altogether derived from external and material objects, and since like can only be known by like, the mind and the external world must be of similar nature; both must be material.

Moreover, as God is the Cause of the world, and the effect resembles the cause, the world cannot be separated from God. God and world are one, and the two names merely indicate different points of view. The same great living thing is called God when contemplated in its wondrous activity; it is called the world when we see but passivity. The world is God's body, God is the world's soul.

Following Heraclitus, the Stoics in their Pantheism saw the corporeal energy of the universe, which they named God, under the form of a continually working Fire or Ether that moves in perpetual cycles, with change in every part and permanence only in the whole.

Since every part of the huge living universe is equally instinct with Divinity, perfection belongs alike to the whole and to its parts as conditions of the universal order and harmony. As subjected to unalterable unity in every change, a fated Reason rules with an absolute impersonality and inexorable justice. Nothing in the whole system is amiss, nothing is in vain, for everything is gathered.up in the strong hand of law that in eternal rationality regulates the whole universe in endless perfection.

\section{Sec. III.-The Theory of Virtue.}

(a) General Principles.-Since the universe is perfect, man's relation to it consists in causing his individual action to accord with the general symmetry and reason. His sole duty consists in living as near the universal perfection as he may, and therefore the demand of virtue is "life according to

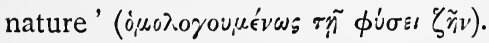


(b) The Criticism of Pleasure.-The universal perfection and rationality being man's guide in action, it follows that the irrational impulses of pleasure can have no part in virtue. For virtue is the aim of effort, while pleasure is only a result of effort. Moreover, the great nature of the universe consists of parts duly ranked in subordination to the whole, and he who 'follows nature' must adopt the same symmetrical principle; but plaesure isolates the individual within his own little range of feeling, and therefore shuts him out from participation in the larger order of nature. Pleasure and passion therefore are the ills and diseases of the soul, its 'mad motors,' against which he who would be virtuous must wage unceasing war.

(c) The Position of 'External Goods.'-When pleasure and passion are to be eliminated from the equating of the virtuous man and Nature, it follows that the pursuit of wealth, the crystallized means towards enjoyment, must be an object of indifference. All that is outside the control of the will is utterly unimportant to the man whose life is firmly set upon an approximation to the standard of ideal virtue. All that gives pleasure partakes of its irrationality, and hence is beneath the choice of an aspirant to the ordered rationality of nature. Therefore, all 'external goods,' health, wealth, even life itself, are morally indifferent, and when circumstance has carried its war against the will to the uttermost, instead of capitulation, the mind that follows right can throw down the gauntlet to fate by taking leave of a sphere that cramps its freedom without humbling its lofty spirit. Life is thus outside the will, and it can at any moment be forsaken, like a chance companion, as was practically proved by many a Stoic teacher.

Though everything that is beyond the will's control is, from the moral point of view, alike indifferent, it does not follow, as the Cynics taught, that they must be sunk to a dead level without a single distinguishing feature. Though unable to supplant virtue in the good man's will, external things are not to be deprived of the slight infinitesimal value they sometimes pos- 
sess. To deny it would be to turn away from the plain teaching of nature. Therefore, while all outside the will is alike indifferent when contrasted zeith virtue, as aids or hindrances to virtue, external things have a kind of worth too little to be compared with the majesty of virtue, but enough to aid in the realization of its full power. The good man will therefore prefer certain indifferent things, such as wealth, not for its own sake, but for the facilities it gives him for moral action, and use them without being beholden to them. He will also avoid others, lest they should cramp his effort; while a third class of occurrences, that cannot impinge upon the exercise of the will, are not only indifferent, but beneath either preference or avoidance.

(d) Virtue.--When everything outside the will has been separated from Virtue, the moulding of the will to the larger rationality of the universe is the sole object of Ethics. Therefore virtue must be an active knowledge or practical wisdom that struggles forward towards the greater reason. Vice is the absence of virtue, and hence it is folly, depravity, imbecility.

Since virtue is obedience to the commands of wisdom, no act is virtuous unless it originates directly from a right disposition of the reason. Though to the eye of another an act may satisfy every law, it is without moral worth unless it has originated pure from the supreme fount of virtue in the mind of the doer.

However the manifestation of virtue may vary, the disposition of the mind must ever be the same, and, therefore, all virtues are of equal merit and all vices of equal depravity. He who is good is good throughout, and the vicious man is altogether vice.

(e) The Ideal of the 'Wise Man.'-Since Virtue is the unfaltering exercise of Reason and Wisdom, the crown of virtue belongs only to the ideally wise or completely good. The 'Wise Man' has gained full control of the passions, and 
he is lord of his desires; therefore, he alone is a true king, revelling in absolute liberty. $\mathrm{He}$ is altogether lovely, for virtue alone is beautiful. As possessor of the goods of the soul he has an inexhaustible treasure-house, containing the whole world's wealth. With rich wisdom the Wise Man looks to earth, and in his perfection excels in every relation of life; he alone is the best ruler, the truest subject, the best general and deepest poet. He alone understands the ways of the Gods, therefore his piety is complete, and he is the oniy real priest and friend of Heaven. Free from want, absolutely perfect and sublimely happy, he is the compeer of Zeus in greatness and majesty.

\section{B.-EPICURUS AND HIS FOLLOWERS.}

Sec. I.-The Epicurean Society.

It is one of the remarkable coincidences of history that the date of the birth of Zeno of Citium is also that of his rival Epicurus. As the condition of Greece at the close of the fourth century before Christ evoked philosophical speculation, invariably one sided in its conclusions, the Stoic exaltation of man's moral destiny to ideal grandeur is fronted by the reiterated claims of individual happiness expounded and practised by Epicurus. Thus in the hands of the Stoics, man, as a moral agent, strives to fulfil his destiny by the narrow road of virtue; under the guidance of Epicurus, man, in the concrete life of sense, finds the goal of his being in the pursuit of happiness.

The life of Epicurus, as befits the Apostle of tranquil satisfaction, was singularly devoid of incident. He was born at Samos, and appears to have had a scanty education. Wandering to Colophon, Mitylene, and Lampsacus, he reached Athens at the end of the fourth century. As a teacher he opened a school in his garden, whither all who felt the pressure of the times flocked as to a haven of refuge. The genius of 
Epicurus impressed itself upon his companions, and they perpetuated his teaching without addition or alteration. The bond that united the society was less the desire of knowledge than the longing for an oasis of calm and rest shut out from the turmoil of ordinary life. Every guest in the garden of Epicurus was the friend of his fellows - a friendship more celebrated than the Pythagorean; for the common bank, to which the Pythagoreans contributed, was superseded by the implicit trust of well-tried friends. Thus with mutual provision for material wants, the Epicureans lived in an artificial paradise, devoted to the culture of happiness and the pursuit of a life of even tenor, diversified by no keen delights, and broken by no sharp sorrows.

The friends and successors of Epicurus cared little for the theoretic development of their philosophy, and hence none of them can claim a place beside their master. Of the earlier Epicureans, Metodorus died before Epicurus, and for nearly two hundred years leader was followed by leader without especial result. In the first century (в.C.) a few names emerge that have become important from intrinsic considerations. Phædrus, in his exposition of the theory at Rone, gained the attention of Cicero. Siro, or Sciro, was the teacher of Virgil, and about the same time Lucretius, the poet, popularized the physical portion of the theory in his verses.

\section{Sec. II.-Logic, or Canonic, and Physics.}

Like the Stoics, Epicurus understands by Philosophy not the Science of Truth, but an Art of Life; or, as he defined it, the realization of a happy life by maxims and reasoning. The preliminary steps of Logic and Physics were even more hastily passed by Epicurus than by the Stoics, and his disciples shunned them as the restless foes of the settled tranquillity of mind that formed the first condition of happiness. Thus the Epicurean treatment of such problems is negative rather than 
positive, and they are satisfied with the erection of a fixed boundary that, like the great wall of China, curbs every inroad upon their peace.

(a) Logic, or Canonic-The great object of Canonic is to bridle the impetuous questions into the reality of truth and knowledge. As the beginning of knowledge lies with the senses, so their impressions are always true. When an impression has been frequently repeated it produces memory, which partakes of the inviolability of the feelings from which it arises. Hence truth belongs to all actual impressions of the senses, and generalizations actually derived from them. When we pass beyond the immediately-present feeling, and form opinions or draw conclusions from it, there is a wide field of the possibility of error, and it is here that all false judgment must be sought.

(b) Physics.-With this simple equipment the philosopher can approach the inmost secrets of nature, The haunting spectres of an unknown and immeasurable universe are dispelled by the system of Atomism that pieces together all things in an evenly-balanced mechanism, with security for man under the calm of unbroken law. Thus Epicurus held the Atoms and Void to be the origin of the universe, and he modified the theory only in two main particulars. The number of the forms of the Atoms must be limited, not unlimited. Moreover, partly in deference to criticism, partly to avoid the idea of compulsion, the Atoms fall not in straight lines, but with slight deviations, from which arises the rebound that was insusceptible of proof in the earlier theory. From the concussion Atoms are grouped together until an infinite number of worlds is formed, that stud the gulf of immensity, each isled in self-completeness, and separated from its neighbour by an interspace of emptiness.

Upon our world life at first appeared in varied forms, but only the best have survived. Amongst living animals, besides the Atoms of flame or fire, there is a still more ethereal sub- 
stance, transmitted from parent to offspring, which is the germ of life and feeling. In man, moreover, there is an additional part to which he owes his rationality. Death rudely cuts the bond that unites the Atoms, and they are dispersed to form new combinations in the infinite movement to which they are subjected.

The universal reign of law in the varying binding and unbinding of Atomic combinations is absolutely unbroken. It is only man's timidity that sees the foresight and providence of the Gods in the changes of the world. On the contrary, it is the sublime privilege of Godhead to realize the ideal of happiness in complete freedom from care. The Gods are immortal beings, with etherealized bodies, human in form, but composed of the purest light. Removed from the distracting cares of humanity, they

\section{'Haunt}

The lucid interspace of world and world,

Where never creeps a cloud, or moves a wind,

Nor ever falls the least white star of snow,

Nor ever lowest roll of thunder moans,

Nor ever sound of human sorrow mounts to mar

Their sacred everlasting calm.'

\section{Sec. III.-Ethics.}

When the stability of knowledge has been established by the Canonic; the universe regulated by law, the dread 'unknown of death' and the fear of Gods resolved in the Physics, it only remains to establish the goal of action by Ethics.

Since the senses are the source and test of knowledge, their gratification is the sole object of effort. But momentary pleasure is evanescent, and the wise man will seek rather the tranquil enjoyment that endures and irradiates the whole life. It is the office of the judgment to decide the relative worth of various enjoyments, and to determine whether the consequences of a present gratification are alien to future tranquillity.

Hence Happiness consists less in the active endeavour to secure bliss than the steady maintenance of a settled peace, for 
pleasure, at the best, is but the satisfaction of a want, and he who is free from want is already happy. To secure this imperturbability of spirit, the claims of the pleasures of the mind must be fully recognised, for they are most lasting, and chief amongst mental joys are the pleasures of virtue, freedom from prejudice, from the fear of pain and suffering, and the moderation that teaches self-control.

When man steps beyond his own individual inner life, the distinction between material and mental joys determines his relationship to his fellows. The necessity for tranquillity amidst his surroundings justifies the existence of the State. None save the philosopher recognises the fear and disturbance following inroads upon the peace or security of his neighbours, and the majority of mankind can only be deterred by the threat of punishment, executed, if need be, by the State. Thus material welfare binds men into communities governed by common laws. On the other hand, the higher joys of life are only realized to the full by the society of congenial natures that adds a rounded completeness to the bliss of the completely happy man.

The portrait of the sublimely lappy' man is a companion picture to the idealized wise man of the Stoics. He is rich in the fewness of his wants, content with little, an unfailing judge of the claims of different pleasures, and absolute lord of his desircs. Destiny and fortune are powerless to prevail against him, for he is armed with contentment and calm tranquillity, against which what is external to himself is all but powerless. Thus, complete in the most enduring bliss, he dwells as a God amongst mortals.

\section{C.-SCEPTICISM IN IHE NEW ACADEMY:}

Sec. I.-Scepticism as a School of Philosophy.

It is a singular instance of the decrepitude of the closing period of Greek Philosophy that its limited effort after an 
original solution of the problem of life is both opened and closed by Scepticism. Pyrrho* and his isolated followers were silenced by the 'criteria' that were boldly proclaimed as infallible touchstones of truth, and two rival dictatorships were thus established that suppressed every expression of adverse opinion and coerced the suffrages of the reason. These haughty claims were soon fronted by renewed revolt, and instead of annihilating doubt they were forced to admit it as an equal in the ranks of philosophy.

This fact forms the distinction between the Scepticism of Pyrrho and the new Academicians. The conflict of manners and interests in the decline of Greece gave birth to the earlier Scepticism, the conflict of the philosophic remedies for the national evil was the origin of the later. The earlier Scepticism taught individual suspense of judgment, the later urged the same policy as the goal of philosophy. The earlier scepticism arose from the blank silence ieft by the death of Aristotle and unbroken by the inaction of his followers, while the later was opposed to the effort demanded by the anchorites of Virtue or the votaries of Content and, standing aloof from the contest between them, maintained that man's destiny and happiness lay not in the solution, but in the avoidance of the dilemma. Lastly, Pyrrho was without a school and without accredited disciples, while the later Scepticism was received into the Academy and nourished by those who claimed to be the spiritual heirs of Plato.

The earlier members of the Academy gradually deserted metaphysics, and after the time of Xenocrates they limited their inquiries to Ethics. $\dagger$ At first marked by erudition, the school in the beginning of the third century (в.с.) was disposed to despise all learning, and hence, when the Stoics and Epicureans became violently opposed, their differences were construed by the weaknesses of the time into existent and unavoidable con- 
tradictions, not of the schools, but of nature. It was thus that the Academy became the rallying point of Scepticism.

This step was taken by Arcesilaus, who succeeded Crates.* The followers of Arcesilaus are of little account, and they are generally grouped together as the Second Academy. The New, or Third, Academy was founded by Carneades, a man of great eloquence and dialectic ability, who followed the direction marked out by Arcesilaus. After his teaching had been perpetuated for some time another new direction was given to the school under the title of the Fourth Academy.t

Sec. II.-The Scepticism of Arcesilaus and Carneades.

The Stoics were the chief champions of certainty, and they believed that their doctrine of the Criterion riveted truth in an impregnable panoply of proof. Arcesilaus replied that their whole work was vain and illusory, for there is no Criterion, and no such thing as truth. The criterion was alike false and impossible in application-false because the conviction that accompanies groundless judgments often equals that which belongs to those that are supposed better founded, and impossible because no judgment has a mark of truth distinguishing it from others. But if there be no criterion there can be no truth, and therefore the mind of the wise man is ever open to any alternative, while he can never stake his assent upon the truth of either. The ideal condition of the philosopher is therefore an impassive imperturbability that denies all knowledge without affirming its impossibility. In action this belief guarantees him from the toil and care of decision; when every path of effort is open he will make no definite pronouncement, but, following the course of probability, decides by the strongest incentives of the moment.

Carneades followed the same path, but his criticism was of wider range, and he expressly denied the existence of any

* See p. 45 . $\dagger$ See p. 76 . 
certainty. Truth and error are in reality inextricably blended, and each is so like the other that every true judgment can be balanced by a false one, similar in every characteristic. Moreover, the idea of certainty is founded upon proof, and every process of proof must either assume the conclusion or lead to an endless series of syllogisms. An end may indeed be sought in the stable existence of God, but if the existence of God be established, as an inference from the symmetrical arrangement of the world, the conclusion is illegitimate, for the world is full of evils. The same thought was enforced in the field of Ethics and action, where man must follow the advice of Arcesilaus, and act as probability determines.

\section{CHAPTER II.}

\section{ECLECTICISM.}

\section{Sec. I.-General Characteristics.}

THE establishment of Scepticism as a philosophic creed was the last act of independent energy in Greek philosophy. Many doctrines were enshrined in the different schools, but there was no creative energy to gather together their several elements of truth, and bind them into a comprehensive system. Instead of progress there now comes amalgamation, and the tendency of the leaders of thought was to incorporate the most popular tenets of their rivals into their own system with the least possible displacement of the original materials.

This change in the attitude of Greece towards philosophy was a natural consequence of its decay, but it was accelerated by the growth of Rome. Gradually Greece lost her freedom, and her philosophy followed other treasures of her intellect and energy to the homes of her conquerors. The Romans were not slow to appreciate the homage of so many arts and sciences to their arms, and the youth of Rome was educated by the sages 
of Greece. With other teachers, the philosophers flocked to Rome and introduced their various systems.

This course was fraught with momentous issues in the highest degree detrimental to the progress of the deepest speculation, for philosophy is the etherealization of the finest powers of a nation, and it cannot survive the decay of people whose labours gave it birth. The teaching of the Romans by the Greeks was, at the time of the fall of Greece, especially anomalous. The pupils were all-powerful, and the relative claims of philosophical systems were judged by those who were but half educated in them. The teachers, dependent upon popularity, were thus forced to follow the lead of those whom they taught, and philosophy abandoned the insight of reason for the general consent of mankind, thus signing away by a single melancholy deed of cession everything that had been won by over four centuries of the toil of the noblest intellects of Greece.

When the Romans began to philosophize, the prevailing tendency of collocation of different views, or, as it has been called, Eclecticism, was further augmented. IVanting the subtlety and speculative earnestness of the Greeks, they failed to recognise the intimate connection of Metaphysics and Ethics, and, always nobly maintaining the dictates of morality, they fitted them with a metaphysical superstructure, or often adopted one altogether alien from them.

\section{Sec. II.-The Fourth and Fifth Academies.}

The doubt that animated the New Academy was toned down by time, and instead of an antagonism to knowledge, it took the form of the admission of an attitude of mind midway between bare probability and certainty. Philo of Larissa first led the Academy in this modification of the Scepticism of Carneades, and the school under his leadership is known as the Fourth Academy. He agreed with Carneades in denying 
the possibility of absolute certainty, and from this point he neared the Stoic doctrine of a criterion while expressly arguing against it. For, he reasoned, if we are to act we must have some guarantee beyond mere probability; there must be a conviction in the mind sufficient to influence the will. Such a conviction, while falling short of certainty, possesses an obviousness that influences without coercing our actions.

This view still left the determination of the criterion of the ground of action precarious and undetermined. A fresh movement towards a philosophic test of the determinants of action was advocated by Antiochus of Ascalon, the teacher of Cicero, who is named the head of the Fifth Academy. Influenced by the desire of the Romans to amalgamate the prevailing doctrines of the schools into a sufficiently sure foundation for action, he held that Truth was not a matter of insight, but the poll of opinions; it was that upon which the chief philosophers were agreed. By uniting random portions of the theories of Plato, Aristotle, and the Stoa, he formed a motley body of propositions, which he maintained were held in common by the three schools. In Ethics he urged the Platonic and Stoic sufficiency of virtue, modified by Aristotle's plea for external goods.

After Antiochus, Potamo, a contemporary of Augustus, expressly named the school Eclectic.

In the first centuries of the Christian era the Platonists devoted themselves to the study and defence of the writings of Plato; but the majority of their work shows a striking grafting of Aristotelian and Stoic teaching upon the original theory. Amongst many men of remarkable genius and learning, this period is especially marked by the name of Plutarch of Chæronea, the celebrated biographer.

Sec. III.-The Stoics.

The gradual growth of the Stoic school by the labours of successive thinkers, as well as its reverses under the searching 
criticism of the Sceptics, led the later members to repair its sinking prestige by stealthy borrowings from other systems. Boethus bowed to the attacks of the Sceptics by ranking the other phases of consciousness with intuition* as criteria. $\mathrm{He}$ also gave up the perpetual dissolution and re-creation of the world, which he replaced by Aristotle's theory of its eternity.

The introduction of Stoicism to Rome by Panætius (the author of a work upon Duty which formed the model of Cicero's treatise upon the same subject) was inevitably followed by a further spread of Eclecticism. The Stoic idealization of duty found a ready echo in the sturdy patriotism of Rome, while its speculative foundation fell upon the dull ears of men imbued with the spirit of action. Hence Panætius and his pupil Posidonius were inclined to follow the same tendency, abandoning the speculative foundations of Ethics, and thus nearing the more popular portions of the theories of Plato and Aristotle, while they steadily ignored the Cynic elements in original Stoicism.

Among the noblest of the Romans the Stoics gained many adherents. Cato of Utica was one of their earliest converts. Cicero, the Roman historian of Philosophy, is Stoic in his hostility to the Epicureans, without accepting the austerity of the doctrines of Zeno. In his scanty Metaphysics he follows Carneades and the New Academy, declining to throw in his lot with any of the contending parties. A few years before the death of Cicero a school was founded in Rome by Q. Sextus, who accepted the practical precepts of the Stoics without their theoretic principles.

The most illustrious pupil of the Sextian society is Seneca, the ill-fated teacher and adviser of the Emperor Nero. Like the other Roman Eclectics, he has little interest in the Stoic Metaphysics. The woe of the world fills the whole horizon of philosophy, and there is no place for mere speculation. The 
conflict of reason and passion leads to Plato's longing for the unbroken calm of death. To reanimate the failing forces of right, he follows Plato, diverging from the Stoics in granting additional powers to the Reason, which is the latent spark of Divinity in man, and its dictates the human utterance of the will of God. By the homage of the reason, in the sanctuary of the breast, must the Deity be worshipped, not in temples nor by sacrifice.

Contemporaneous with Seneca lived Musonius. In his aversion to speculative inquiries he gives up much of the Stoic theory nearing Cynicism, while in his wide philanthropy he again approximates the popular teaching of the later school. Philosophy, he argued, is the cure for the diseases of the soul-a cure that cannot be wrought by mere learning, but by practice. The seeds of virtue are implanted in us, but their nurture must be our own work. We must therefore know our powers, and this is all that philosophy can teach. But our sole concern and our sole power is the execution of our thoughts, and all beyond, as out of our control, is beneath our care. Only in developing the germ of virtue can happiness be found, and all else is an alien power to which we must unconditionally surrender.

If in the system of Musonius the philosopher is the physician of the soul, his function with Epictetus is the priest and servant of God. Agreeing with the Stoic, Cynic, and Aristotelian elements of his predecessor's teaching, Epictetus urges his followers to the exercise of a comprehensive benevolence that unites men together and brings them into community with God.

Marcus Aurelius, the celebrated emperor and patron of Philosophy, agrees with Epictetus save in the Cynic portions of his teaching. By position and religious fervour Aurelius is inclined to replace it by the more noble theories of Plato, from whom he borrows the supremacy of Reason, which leads him, in homage to its nobility, to depreciate all that is external to the lofty dictates of the will, which are divine in their origin, and lead man to bow before the throne of Deity. 
Sec. IV.-The Cynics, Peripatelics, and Epicureans.

The continuous adoption of Cynic and Aristotelian principles by the other schools shows a successive teaching of both forms of doctrine. In Imperial Rome the laxity of life called from stern moralists repeated attacks, which, unheeded and fruitless, drove the reformers to the hermitage of Cynicism. This later outbreak is far removed from the rigour that embraced but one of the many sides of the character of Socrates. In later Cynicism there is an utter despair both of the world and Philosophy. Hence their analogy to their predecessors consists rather in the superficial resemblance of their mode of life without a real spiritual kinship.

The followers of Aristotle differed from their rivals of the Academy in remaining true to the theory of their master. They commentated and expounded his works, and fiercely defended them against attacks from every quarter. Nevertheless, the spirit of Eclecticism appears even in their commentaries, and starts out from the treatises they have handed down as the work of Aristotle.

Amongst the frequent shifting of opinions there was only one school that remained true to the principles of their founder. No desire to fortify or enlarge the theory is reported to have penetrated into the secluded garden of Epicurus; probably the original genius of their master dominated successive generations of his disciples, possibly their desire for calm and repose forbade discussion, or the need of defence may not have been felt, owing to the charges of sensuality which were liberally heaped upon them, and which may have exempted them from the ordeal of criticism as beneath the dignity of philosophers.

Sec. V.-Later Scepticism.

The negative criticism of the Scepticism of the New Academy had forced the existing schools to repair the deficiencies in their theories by piecemeal borrowings from other systems 
which had been subjected to similar attacks. It necessarily followed that philosophies that owed their very existence to original differences of opinion could not be consistently pieced together to afford a secure defence against the common adversary. By the substitution of Eclecticism for Scepticism in the Academy, the philosophy of doubt was deprived of a place in the world of thought, and the Eclectics won a brief triumph. As the progress of amalgamation multiplied trivial differences, or surmounted them by perverting their meaning, a feeling of dissatisfaction gradually arose which gave birth to a new body of Sceptics during the close of the last century before Christ.

The new champions of doubt claimed to be the lineal descendants of Pyrrho, though their arguments were mainly borrowed from the followers of Arcesilaus and Carneades. From both sections of their predecessors they were distinguished by an alliance with a body of medical men, known as Empirics, who were in opposition to the tenets of their brethren. Thus the age of ancient philosophy was disturbed by the simultaneous attacks from within and from without. The Empirics in medicine maintained that remedies could only be applied from personal knowledge, and that it was impossible to connect diseases with antecedent causes. The same theory had only to be extended to disconnect all events with causes, and finally destroy the tender filaments that form the woof of knowledge. These conclusions were drawn by Anesidemus, who found the goal of philosophy in the denial of knowledge, which freed man from care, and thus gave him the only happiness that can be found. The historian of the school is Sextus Empiricus (or Sextus the Empiric), who embodied in a series of voluminous treatises all that had been advanced against the validity of knowledge from the earliest times down to Ænesidemus. 


\section{CHAPTER III.}

NEO-P LA T ONIS M.

Sec. I.-The Transition from Eclecticism to the Philosophy of Faith.

AfTER the death of Aristotle the thinkers of the succeeding generation endeavoured, each within the limits of his school, to perpetuate the several doctrines that had been handed down to them. While fondly hoping to protect the territories they deemed already won, they were startled by Pyrrho's proclamation that their toil was wasted and their possessions worthless. Amid a sinking national life, which robbed them of the power to vindicate their claims, it is little wonder that the Academy made terms with their adversary and opened their gates to Scepticism. But there could be no union between philosophy and doubt, and the various schools endeavoured by a combination of their resources to repel the common adversary. Such a course, by concentrating the attacks of the sceptic upon their united weaknesses, would have inevitably hastened, instead of delaying, the final capitulation of philosophy.

When affairs were in this condition, at the opening of the first century before Christ, the intense yearning for finality that characterizes the deepest aspirations of the soul made itself decisively felt. When no one system founded upon reason, nor no combination of systems, was able to endure the onset of the Sceptics, the insatiable hunger of the mind craved another outlet, not by the beaten track of proof, but by the wings of faith. Reason had hitherto claimed the whole field of Philosophy, and it had failed after five hundred years of toil to justify its pretensions. 'To reanimate its exhausted energy, it must be aided by faith. Faith and reason in a close alliance was the sole possible answer to the sneer of the Sceptic and the despair of the ancient world. The union of philosophy and religion was a change so important that it gathered in the 
supreme effort of the greatest civilized nations of antiquity during a period of nearly three hundred years.

The first step in the new direction may be assigned to the followers of Pythagoras. For three hundred years the society had pursued its way as a religious cult, ${ }^{*}$ with a body of mystic observances and a fixed ritual of spiritual dogmas. The members were closely united in a holy brotherhood that struggled towards a higher existence by a mortification of every sensuous desire. At the beginning of the first century before Christ they endeavoured to revive the speculative theories of Pythagoras to justify their religious observances to the reason. In the prevailing eclectic tendency they mingled the number theory with portions of the doctrine of Plato, especially in the later form, which united the characteristics of the Ideas and Numbers. $\dagger$ From this point they diverged in the direction that stamps the revived theory as Neo-Pythagorean by assigning the Ideal-Numbers a place in the mind of God. The Numbers or Ideas were the Divine plan of creation, the eternal model from which the world was fashioned.

While the Neo-Pythagoreans borrowed Metaphysics from the Platonists, the Platonists adopted many traits of the Pythagorean religious creed. Thus there was a strong impetus given to the tendency from the most popular philosophical school and from one of the leading religious societies of Greece.

But it rested with another civilization to finally prepare the way for the coming religious philosophy. At Alexandria Greek wisdom and Oriental civilization met and crossed. There the leaders of every science and every art found a home and eager followers. Almost all the schools of philosophy were well represented, and Anesidemus was carrying on the siege of Eclecticism by a new force of doubt. 'Greek Scepticism, Judaism, Platonism, Christianity-all have their interpreters within so small a distance from the temple of Serapis.'

Here Philo of Alexandria, a Greek by education, by birth a

* Page 5 .

$\dagger$ Page 45. 
Jew, lived and taught from 30 B.C. to 50 A.D. An ardent admirer of Greek philosophy and a devout worshipper of the Jewish Jehovah, he endeavoured to combine the two in a religious system that would satisfy the reason, while supplementing its deficiencies by the supreme fiat of Revelation; and it is only by the Idea of God that both can be firmly united.

God, he taught, is the infinite expression of every infinity. Every human thought that would endeavour to mount to the ineffable majesty of the Godhead shrinks back dwarfed by its finitude. For us it is enough to believe in His existence, seeing in it the sum and source of all perfection, the infinite Power that is the cause of all.

Between the infinity of God and the imperfection of the world Philo's predecessors placed various intermediate steps. The mass of mankind have a fixed belief in demons, and the Platonists a World-soul. Such attempts to bridge the gulf are summed up in Philo's Logos. The Logos is the Divine Reason flowing from God, His ambassador, servant and minister. $\mathrm{By}$ the agency of the Logos, God formed the chaotic mass of primeval matter into the world, where man possesses a part of each side of cosmic antithesis, his body from matter, and his Reason pointing him to the universal Logos. Being thus formed, it is plainly his duty and happiness to nourish the spiritual germ and separate it from the clogging desires of the body. To him who has courage to rise ever upward towards perfection a great reward is promised. By rigid castigation of the body he mounts higher and higher, gaining fresh powers, until, passing every lower range of being, even the Logos, in a sublime ecstasy losing the last limitations of finitude, he is absorbed in the infinity of Deity.

\section{Sec. I1.-Plotinus.}

For nearly two hundred years the majestic thought rudely shajed by the genius of Philo of Alexandria remained un- 
developed. Before the middle of the third century (A D.) Ammonius Saccas left his work as a labourer, and became the 1.ader of the Alexandian Neo-Platonists. Amongst his pupils were Longinus, possibly Origen, and Plotinus, his successor, who wove the many elements of Jewish Theism and Greek Philosophy into a comprehensive religious philosophy. Soon after the deah of Ammonius Saccas he moved to Rome, where he died in the year 270 A.D.

(a) The Supreme Principle of Plotinus. - The teaching of Philo connected God and the world by the supposition of the Logos. To complete his thought it was necessary to show the descending grades by which the Infinity of Godhead passed downwards until it gave birth to the material world, without forfeiting the smallest degree of perfection. To make the chain of existences complete, the supreme First Principle must be raised above the conception of Philo. It must be sphered in an absolu:e infinity, and therefore denied all attributes. The 'First' must be without thought, for thought implies distinction, and distinction finitude. It must be without will, for will is directed to what is beyond the doer, and therefore involving limitation. It can at best be imperfectly described as One and Good, yet always with the restriction that both suppose an opposition; for plurality is opposed to unity and ill to good, and the sum of all must contain all things. Nay, in the First there can be no division, not even the sundering of an individuality that is presupposed in the unity of consciousness, and therefore it is the sublime negation of thought, will, and personality, the great gulf of infinity that can only be distinguished by the denial of every attribute that is tainted by the finitude of humanity.

(b) The Principle of Reason (or voü:).- Such is the transcendent perfection of the 'First' that the majesty of its infinity sheds forth a lesser radiance without loss or division. This emanation stands next to its great prototype, and is called Reason. Its lofty privilege is to see into the inmost nature of 
all things, and to discern their unalterable relations. For it there is neither past nor future, and its existence is sphered in a measureless eternity that time but vainly copies.

(c) THE Soul. - From Reason proceed Life and Activity, which form the lower grade of the living Soul, the great rational Life. As issuing from the radiancy of Reason, it shares in the timeless Ideal order; as endowed with the privilege and penalty of life, it inclines toward the material over which it watches, and to which it communicates the higher order of Reason.

(d) The World-Soul and Matter.-Life nust be realized in the change of matter, and the Reasoning Soul completes itself by the emission of the Soul of the World that is the life and principle of Chaos. Lastly, the World-Soul completes itself by shedding forth the inert matter that serves it as a body. Thus as light at last ends in darkness, so the emanations of the great First, the primai Infinity, are at last $\mathrm{com}^{-}$ pleted by the remote product of matter.

(e) The Reverse Path-From Man to the 'First.'Man is a miniature of the Soul of the World. As with Philo, by his body he touches the remote verge of creation, while by virtue of a higher principle he is akin to loftier existences. By rigorous purification of all that fetters hin to matter he may win back a toilsome path to the Infinite. This is his whole duty, and the sum of every virtue. As he annihilates the yearnings of sense he soars above the desires of Life, gradually mounting to the lofty state of the great Reason (võ̃s). To quit the limitations of thought he must bury himself within his own spirit, and, losing every distinction, float in a swoon of ecstatic bliss into the broad bosom of the shoreless Infinite.

Sec. III.-Iamblichus.

After the death of Plntinus, the leader of the new phase of thought was Malchus of Tyre, better known as Porphyry. 
After his death the chief seat of the school was transferred from Rome to Syria, where Iamblichus developed the religious side of Neo-Platonism. Under his powerful personality and dexterous management the learning and civilization of the old world disputed the early claims of Christianity to the leadership of the religions of the earth. In theory he marshalled the emanations of Plotinus into a hierarchy of divisible essences midway between spiritual beings and metaphysical substances; in practice he urged the severest asceticism as the sole path to virtue and bliss. During a period of fifty years the new doctrine advanced with giant strides. In Palestine, Rome, and Alexandria it girdled the intellect of the fourth century, and its climax was reached when the Emperor Julian ascended the throne with the avowed intention of establishing religious philosophy as the creed of the civilized world. After an almost unparalleled career of conquest he died before his desire was attained. Little more than half a century later the ill-fated Hypatia was murdered by the Christian rabble at Alexandria, the stronghold of Neo-Platonism (A.D. 4 I5).

\section{Sec. IV.-The Last School of Neo-Platonism.}

After the death of Julian, Neo-Platonism suffered the fate of a conquered faith. Its philosophers felt the keen blast of adversity, and instead of spiritual leaders they became a persecuted sect. Suffering had proved a hardy discipline to the growing energy of Christianity, but it hastened the end of an enfeebled philosophy. Yet under trial the philosophical schools showed the dignity of a patriarch, conscious of noble purposes not unfulfilled, who would leave no jarring memories behind. The surviving schools, chief amongst them the Academic and Aristotelian, after leading the thought of Greece for over seven hundred years, reconciled their differences, and accepted the religious faith of the Neo-Platonists.

For a century and a half, marked by the name Proclus, the 
inain body of philosophers were united at Athens, and though little was added of historical importance, they gathered in the wisdom of antiquity for the admiration of posterity.

'The end of philosophy in the Western portion of the Roman Empire may be dated from the death of Boëthius (A.D. 525), and in the Eastern four years later, when the Emperor Justinian confiscated the property of the Academy, forbade the teaching of philosophy, and banished the last of those who venerated the results won during a thousand jeurs by independent speculation and fearless inquiry. 


\section{INDEX OF TERMS AND GLOSSARY}

ACTUAlity ('̇ขé $\rho \gamma \varepsilon \iota \alpha), 52$ ámá $\theta \varepsilon \iota \alpha, 66,68$

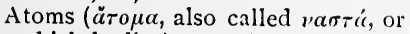
thick bodies), I5, I6, 70

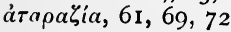

Beginning ( $\alpha \rho \chi \eta \dot{\eta}), 3$ Boundless, The ( $\left.\ddot{\pi} \pi \varepsilon \varepsilon_{0 o \nu}\right), 4$

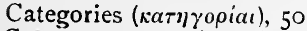

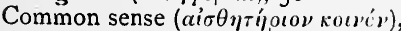
54

Condensation ( $\pi \dot{\kappa} \kappa \nu(\nu \sigma \iota \varsigma), 5$

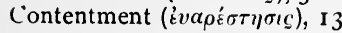

$\delta \delta \zeta \alpha$, opinion as opposed to know. ledge; a rude but unlleveloped conviction, $37,3^{8}$

है $\rho \omega s, 37$

External goods $\left\{\dot{a} \pi 0 \frac{\pi \rho o \eta \gamma \gamma \mu^{\prime} \nu a}{a \delta \iota \dot{\varepsilon} \phi o \rho \alpha}\right\}, 66$

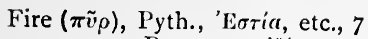

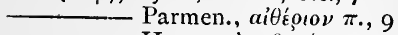

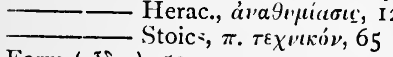

Form $(\epsilon i \delta \circ c), 50$
Full, filled space; plenum as opposed to void ( $\left.\tau \dot{\alpha} \pi \lambda \tilde{\eta}_{0 \epsilon \varsigma}\right)$, I 5,16

Germs of things $\left(\sigma \pi_{\hat{c}}^{\prime}, \mu \alpha \tau \alpha\right)$, also called $\dot{\mu} \mu \iota \mu_{\epsilon} \tilde{\eta}$, that is parts like to the wholes, 17

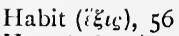

Hate (ขยікос), I4

Idea ( $\varepsilon i \delta o s), 36$

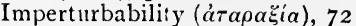

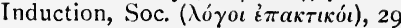
Aris. ('ma $\pi \omega \gamma \eta \dot{\eta}), 49$

Love ( $\phi_{l} \lambda$ ó $\left.\eta \dot{s}\right), I_{4}$

Matter ( $(" \lambda \eta), 51,52$

Moisture ( $\tau \dot{o} \dot{v} \gamma \rho \dot{\nu} \nu), 5$

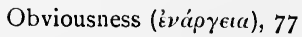

Pleasure and virtue, 32, 7 I, 72 Summum bonum, 55 criticised by Plato, 42

Stoics, 66

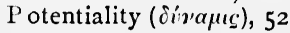

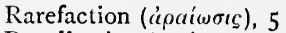

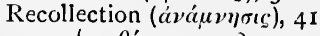

Right $\left.\left\{\begin{array}{l}\kappa \alpha \theta \dot{\eta} \kappa о \nu \tau \iota \\ \kappa \alpha \tau \rho \rho \theta \dot{\omega} \mu \alpha \tau \alpha\end{array}\right\}, 67\right]$

Roots of all ( $\left.\pi \alpha^{\prime} \nu \tau \omega \nu \dot{\rho} i \zeta \dot{\omega} \mu \alpha \tau a \dot{)}\right),{ }_{4}$

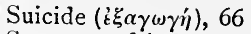

Suspense of judgment ( $\left.\dot{\varepsilon} \pi \chi^{\prime} \eta\right), 73$

Tact ( $\phi \rho o ́ \nu \eta \sigma \iota c), 57$

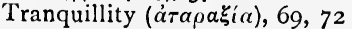

Unlinited, The (á $\pi \varepsilon \iota \rho o \nu), 4$

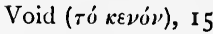

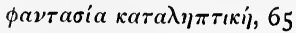




\section{INDEX OF NAMES}

\begin{tabular}{|c|c|}
\hline & \\
\hline $\begin{array}{l}\text { ACADEMr, } 34,45,74,76,77,82,87 \\
\text { Enesidemus, } 81\end{array}$ & $\begin{array}{l}\text { Ecphantus, } 8 \\
\text { Epicurus, 68-71 }\end{array}$ \\
\hline Alcibiades, 27 & Epictetus, 79 \\
\hline Alexander, 46 & Erymneus, 59 \\
\hline Ammonius Saccas, 85 & Euclides, 31,33 \\
\hline Anaxagoras, 16 & Eudemus, 58 \\
\hline $\begin{array}{l}\text { Anaximander, } 4 \\
\text { Anaximenes, } 4,5\end{array}$ & Euthydemus, 2I \\
\hline $\begin{array}{l}\text { Annaximenes, } 4,5 \\
\text { Anniceris, } 32,34\end{array}$ & Gorgias, 21, 23 \\
\hline $\begin{array}{l}\text { Antiochus, } 77 \\
\text { Antisthenes, } 31,32\end{array}$ & Hegesias, 32 \\
\hline Arcesilaus, $45,74,81$ & Heraclitus, I I-I3 \\
\hline $\begin{array}{l}\text { Archytas, } 5 \\
\text { Aristippus, } 31,32\end{array}$ & $\begin{array}{l}\text { Herulus, } 63 \\
\text { Hippasus, } 8\end{array}$ \\
\hline $\begin{array}{l}\text { Aristippus, } 31,32 \\
\text { Aristo of Ceos, } 59\end{array}$ & Hippias, 21 \\
\hline $\begin{array}{l}\text { Aristotle, } \\
45-59\end{array}$ & $\begin{array}{l}\text { Hippo, } 5 \\
\text { Hypatia, } 87\end{array}$ \\
\hline $\begin{array}{l}\text { Aristoxenus, } 58 \\
\text { Aurelius, Marcus, } 79\end{array}$ & $\begin{array}{l}\text { Iamblichus, } 86,87 \\
\text { Idaeus, } 5\end{array}$ \\
\hline $\begin{array}{l}\text { Böthius, } 88 \\
\text { Boethus, } 78\end{array}$ & Julian, 87 \\
\hline $\begin{array}{l}\text { Carneades, } 74,81 \\
\text { Cato, } 78 \\
\text { Chrysippus, } 63\end{array}$ & $\begin{array}{l}\text { Longinus, } 85 \\
\text { Lucretius, } 69 \\
\text { Lyco, } 59\end{array}$ \\
\hline $\begin{array}{l}\text { Cicero, } 78 \\
\text { Cleanthes, } 63 \\
\text { Crantor, } 45 \\
\text { Crates, } 45 \\
\text { Critolaus, } 59\end{array}$ & $\begin{array}{l}\text { Malchus of Tyre, } 86 \\
\text { Melissus, } 9 \\
\text { Metaphysics, Derivation of, } 50 \\
\text { Metodorus, } 69 \\
\text { Musonius, } 79\end{array}$ \\
\hline $\begin{array}{l}\text { Diodorus, } 59 \\
\text { Diogenes of A pollonia, } 5 \\
\text { Dionysodorus, } 21\end{array}$ & $\begin{array}{l}\text { Panætius, } 78 \\
\text { Parmenides, } 9 \\
\text { Peripatetic, Derivation of, } 47 \\
\text { Persæus, } 63\end{array}$ \\
\hline
\end{tabular}


Phædrus, 69

Philo, 83, 84

Plato, 3I, 33-45

Plotinus, 85

Plutarch, 77

Polemo, 45

Porphyry, 86

Potamo, 77

Proclus, 87

Prodicus, 2I

Protagoras, 21, 23, 37

Pyrrho, 6I, 73, 8I

Pythagoras, 5-8

Siro, 69

Socrates, 25-3I

Sophists, I8-24

Speusippus, 45

Strato, 58, 59

Thales, 3

Theodorus, 32

Theophrastus, 58

Thrasymachus, 2 I

Xantippe, 27, 29

Xenocrates, 45,73

Xenophon, 3I

Seneca, 78

Sextians, $78^{\circ}$

Zeno of Elea, 9

Sextus Empiricus, 8I Citium, 63 


\section{DIAGRAMS}

ThE following diagrams are an attempt to present a visible picture of some of the thoughts expressed in the preceding piges. The first series deals with the mutual relations of the three periods of Ancient Philosophy; the second shows the relations of the muin principles of the different groups of thinkers ; and the third the application of these principles.

(i.) It is worthy of note that Ancient Philosophy has three periods, each of which has three divisions. These divisions inay be named Origination, Cumbination (or Development) and Completion. They may be represented, perhaps, most clearly upon a cone, round which an ascending course is traced with vertical lines representing the tripartite divisions of each period. In the two first diagrams this is shown vertically in the first and horizontally in the second. The former has the advantage of showing clearly the retrogressive and destiuctive tendency of the novements of the Sophists and Sceptics, while the second seems to give a better view of the circular but ever upward flight of Philosophy.

(ii.) While the first series shows the relation of the periocis and tendencies, the next group gives the relation of the principles of philosophies as they group themselves together.

(iii.) It may be noted that the third series is not compicte owing to the diagrams omitted being too complicated to appear clearly in a single prge. The method adopted is to use the principle of the second series as a basis, and then add to it such details as give the most adequate view of the constitution of the universe as deducible from the main principle of a given philosophy.

N.B.- It may perhaps be advisable to warn the rexder who is beginning his acquaintance with philosophy, that it is impossible to give an eye-picture of abstract speculdtions; all that diagrams can profess to show is the relation of groups of thoughts without, in any case, presenting a full view of the thoughts themselves. This is especially the case in the first two diagrains, where the dotted lines only enclose thinkers who play a similar part in their own periods, but as these periods are governed by different principles, it follows that the prototype of a later thinker may be found more often in a different column from his own-where the connection between those in the same column is exceptionally close it is indicated in the first diagram by arrow-heads. 
I $\underline{a}^{\text {The development of Philosophy }}$

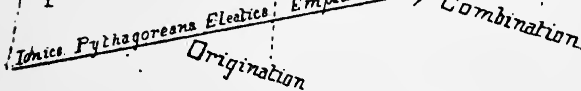

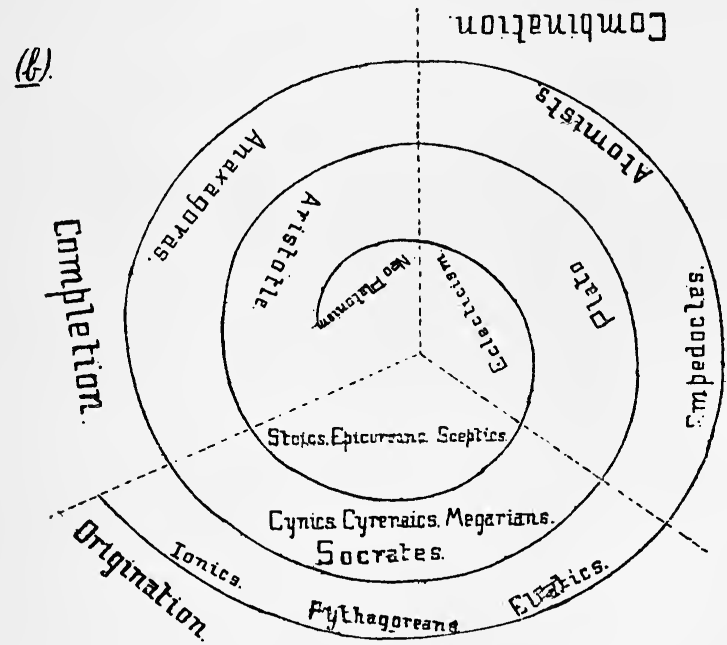


II THE CINNECTION UF THE MAIN IDEAS वF THE

VARIDLS SYSTEMS

A. The Beginning and Chief Characteristics of the World (a). The Tonians. (B). The Pythagoreans. (y).The Eleatics. The Beginning as Matter Numerical form

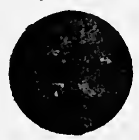

B The Phulosophy of Change

(ब) HERACLITUS

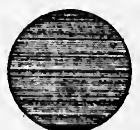
Pure Unity (Being). Change as the Eunal Law.
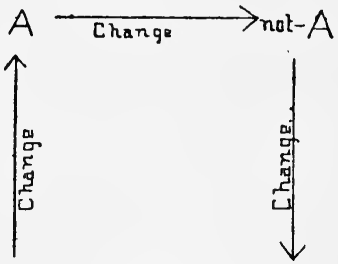

$\operatorname{not} A \longleftarrow$ Chinge. $A$

(B) EMPEDOLLES - Explanation of Change by

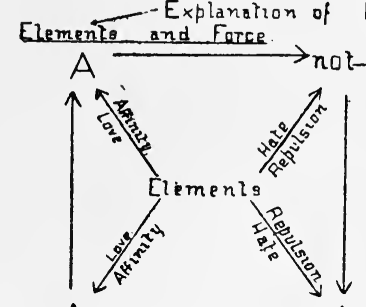

not $A_{\leftarrow}$ A $\operatorname{not} A$

ATOMISTS

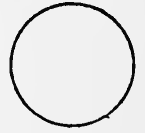

8) $A N A \times A \square \square A A S$

Explanazzon of change by Origunazian of Motzon

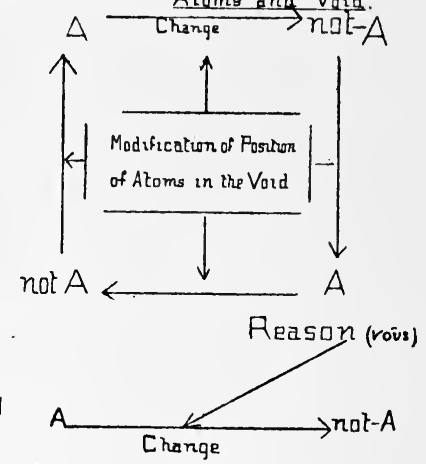


C Doubs

\section{SDPHISTS}

Q a) Krowledge

SULRATES

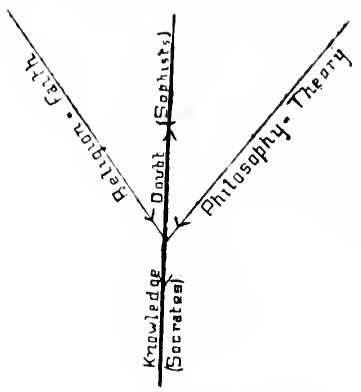

(b) Knowledge in Definition

Socratic Induction

Individual Instances with Atrrotutie

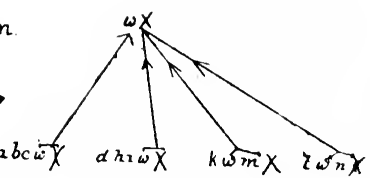

E. PLATE

The Idea
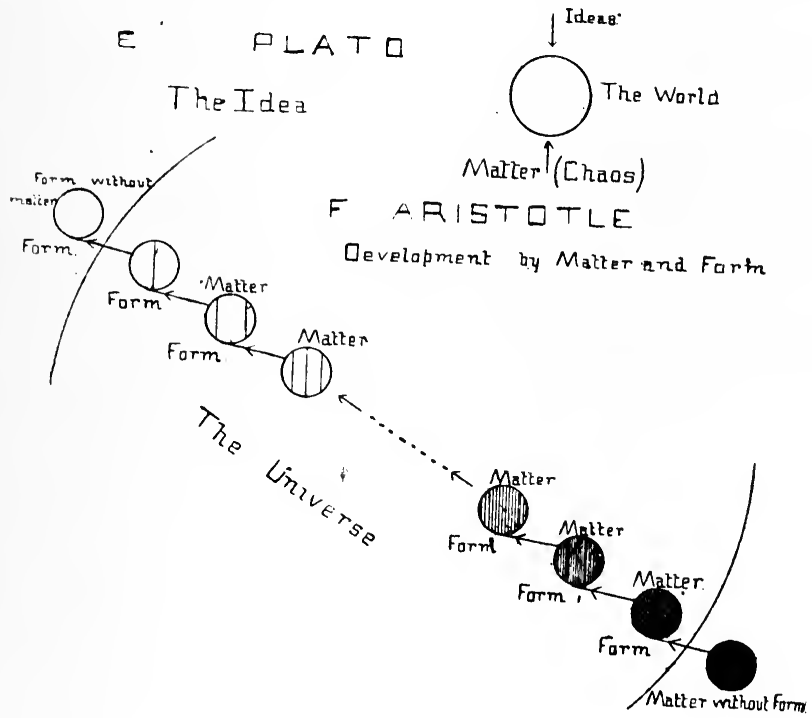
C The Supreme end of Man

\section{STDICS EPICUREANS}

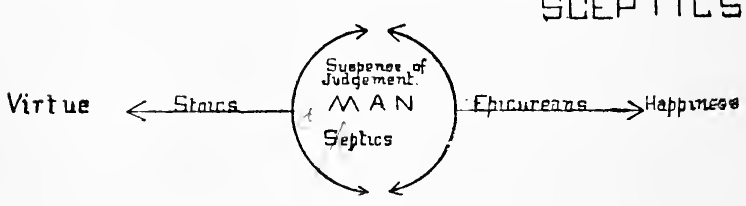

H. Men united to the Infinite by Fauth

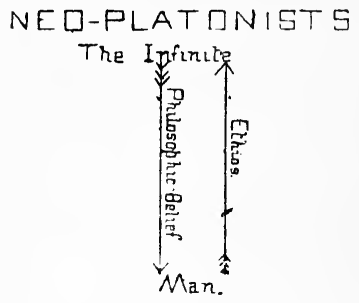

III THE PAINCIPLES APPLIED TO THE FDRMATIDN CF THE WOALC

A. The Primal matter of the Ioniens

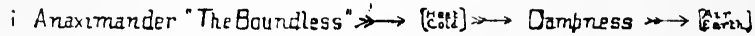

is Anaximines

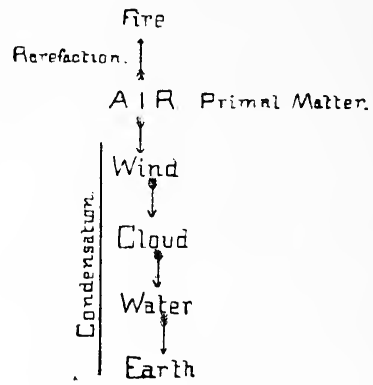


B. Number-Theary of Pythagareans
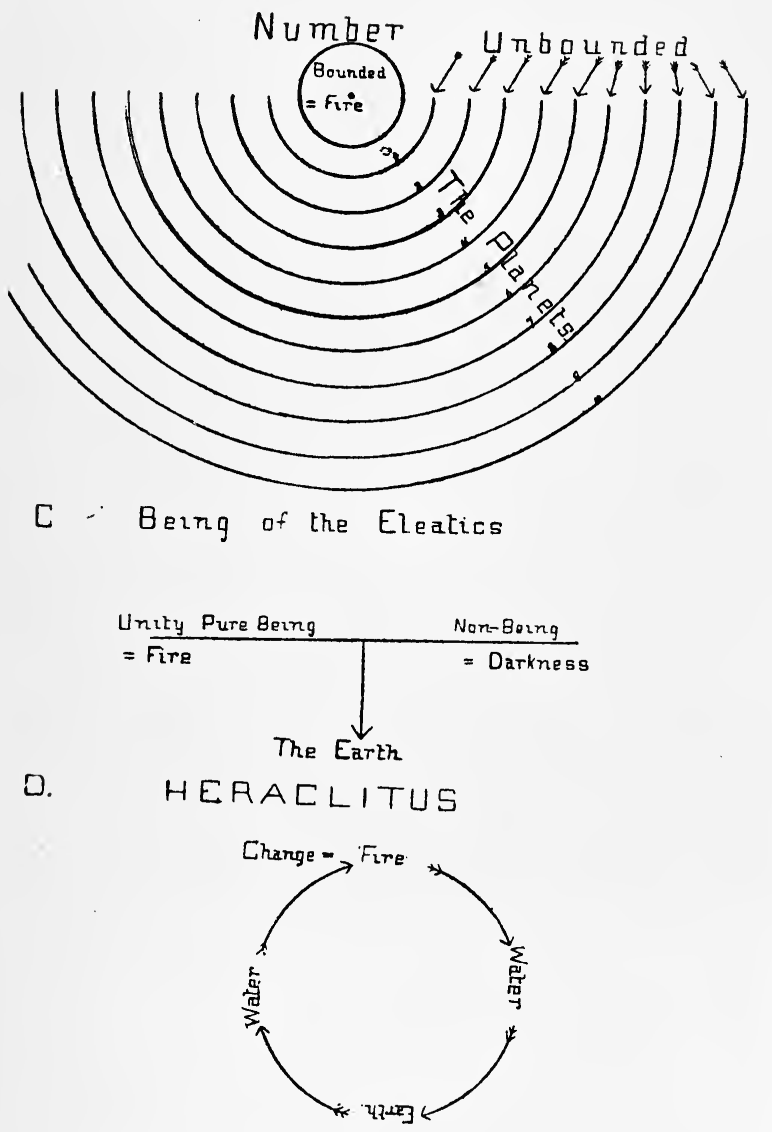


\section{E PLATD}

Ideas under the formative power of Demiurgus

F ARISTOTLE
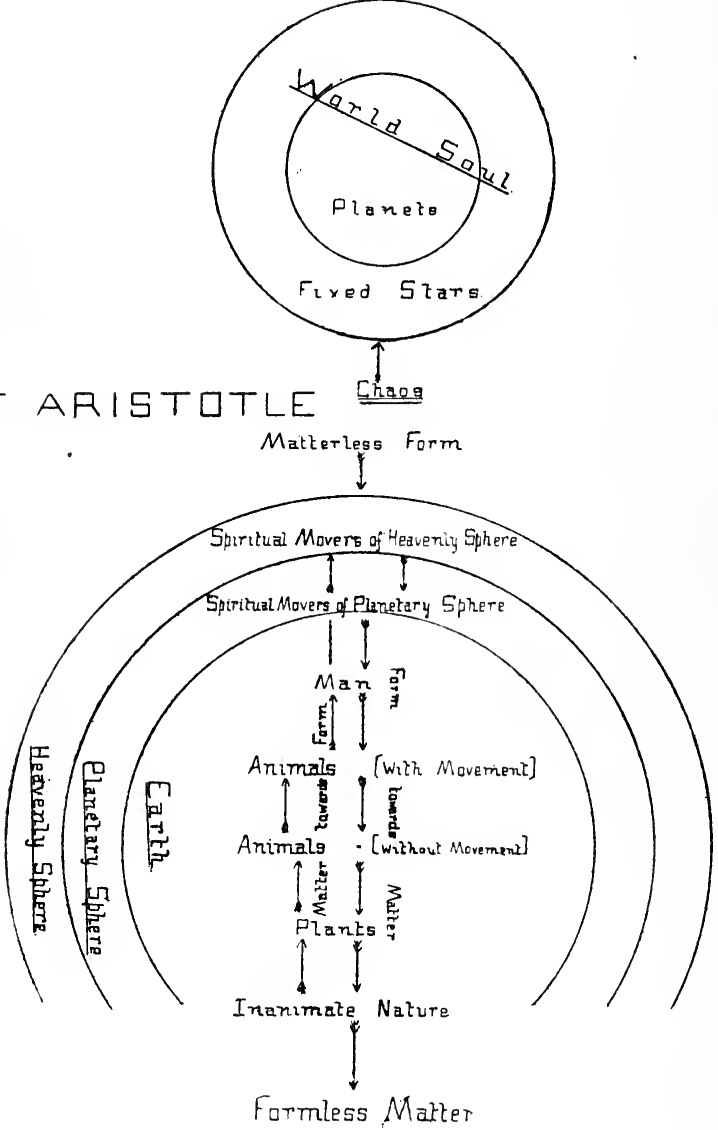


\section{BY THE SAME AUTHOR.}

Nowe ready, cloth, price 3 s.

\section{AN INTRODUCTION TO CUDWORTH'S TREATISE CONCERNING ETERNAL AND IMMUTABLE MORALITY,}

WITH

\section{Sife of Gitdworth and a few Crifical ZTofes.}

\section{PRESS NOTICES.}

'Students of philosophy, and all readers who appreciate the meaning of the poet that called philosophy Divine, will take pleasure and instruction from Mr. WV. R. Scott's " Introduction to Cudworth's 'Treatise concern. ing Eternal an' Immutable Morality.'" The book is very short, but is packed with information as to Cudworth's life and with critical summaries of his main work. . . Mr. Scott's summary, intelligent, and not too appreciative as it is, will serve the purpose of all but the most rigorous students.'-Scotsman.

- These few pages give indication of familiarity with some, at least, of the philosophic thinkers upon whom Cudworth draws, or with whom he has to be set in relation.'-Mind.

"This short "Introduction" is enough to show that Mr. Scott would make a competent editor. . . . Mr. Scott's short "Introduction" and "Summary of the Argument" and "Critical Notes" show that the task of re-editing might safely be left in his hands.'-Manchester Guardian.

'We can commend Mr. Scott's deeds and intentions, and wish him all the success he deserves.'-Theological Monthly.

"The Treatise brought before us deals with "The True Nature of Sense," "The True Nature of Knowledge," "The True Nature of Morality," and of these Mr. Scott gives us a concise and intelligent summary.'-Literary Churchman.

'Mr. W. R. Scott, of Trinity College, Dublin, has given a good sketch of the life of Ralph Cudworth, and a very useful analysis of his "Treatise on Eternal and Immutable Morality." '-Ecclesiastical Gazette.

'Those who desire to gain an insight into Cudworth's Treatise cannot do better than get hold of Mr. W. R. Scott's "Introduction." '-Irish Ecclesiastical Gazette.

"This "Introduction" is in every way suitable and serviceable. Mr. Scott has done his work with ability as well as modesty. To the "Intro. duction " useful "Critical Notes" are appended on "Cudworth and Butler" and "Cudworth and Kant," and a good Index.'-The London Quarterly Review.

IONGMANS, GREEN \& CO., LONDON AND NEW YORK. 


$\therefore \quad 1$

4 
is

! 


\section{PLEASE DO NOT REMOVE CARDS OR SLIPS FROM THIS POCKET}

\section{UNIVERSITY OF TORONTO LIBRARY}

B Scott, William Robert
177 A simple history of ancient
S37 philosophy


